\title{
Title: Enteric viruses evoke broad host immune responses resembling
} bacterial microbiome

3 Authors: Dallari Simone, ${ }^{1}$ Heaney Thomas, ${ }^{1}$ Rosas-Villegas Adriana, ${ }^{1}$ Neil Jessica A., ${ }^{1}$ Wong 4 Serre-Yu, ${ }^{1,2}$ Brown Judy J., ${ }^{3,4}$ Urbanek, Kelly, ${ }^{5}$ Dermody Terence S., ${ }^{5,6}$ Cadwell Ken ${ }^{1,7,8 *}$

$5{ }^{1}$ Kimmel Center for Biology and Medicine at the Skirball Institute, New York University 6 Grossman School of Medicine, New York, NY, 10016, USA

$7 \quad{ }^{2}$ Department of Medicine, Henry D. Janowitz Division of Gastroenterology, Susan and Leonard

8 Feinstein Inflammatory Bowel Disease Center, Icahn School of Medicine at Mount Sinai, New

9 York, New York, United States of America

$10{ }^{3}$ Department of Pathology, Microbiology, and Immunology, Vanderbilt University School of 11 Medicine, Nashville, Tennessee, USA.

$12{ }^{4}$ Department of Biology, Trevecca Nazarene University, Nashville, Tennessee, USA

$13{ }^{5}$ Department of Pediatrics, University of Pittsburgh School of Medicine, Pittsburgh, Pennsylvania, 14 USA

$15{ }^{6}$ Department of Microbiology and Molecular Genetics, University of Pittsburgh School of 16 Medicine, Pittsburgh, Pennsylvania, USA

$17{ }^{7}$ Department of Microbiology, New York University Grossman School of Medicine, New York, 18 NY 10016, USA

$19{ }^{8}$ Division of Gastroenterology and Hepatology, Department of Medicine, New York University

20 Langone Health, New York, NY 10016, USA

21 *To whom correspondence should be addressed: Ken.Cadwell@med.nyu.edu 


\section{SUMMARY}

23 Contributions of the viral component of the microbiome, the virome, to the development of

24 innate and adaptive immunity are largely unknown. Here, we systematically defined the host

25 response in mice to a panel of eukaryotic enteric viruses representing six different families. Most

26 of these viruses asymptomatically infected the mice, the magnitude and duration of which was

27 dependent on the microbiota. Flow cytometric and transcriptional profiling of mice mono-

28 associated with these viruses unveiled general adaptations by the host, such as lymphocyte

29 differentiation and IL-22 signatures in the intestine as well as numerous viral strain-specific

30 responses that persist. Comparison with a dataset derived from analogous bacterial mono-

31 association mice identified bacterial species that evoke an immune response comparable to the

32 viruses we examined. These results expand an understanding of the immune space occupied by

33 the enteric virome and underscore the importance of viral exposure events.

\section{INTRODUCTION}

35 Our symbiotic relationship with the gut microbiota exemplifies host-microbe coadaptation. In 36 addition to the mutually beneficial exchange of nutrients, intestinal colonization by bacteria shapes

37 the development and function of the mammalian immune system (Honda and Littman, 2012;

38 Round and Mazmanian, 2009). A variety of bacteria evoke context-specific responses that

39 influence the gene expression program of the parenchyma and differentiation of leukocyte subsets

40 (Atarashi et al., 2011; Ivanov et al., 2009; Mazmanian et al., 2005). The outcome of these reactions

41 can be advantageous, as in colonization-resistance to pathogens, or adverse, as in chronic disorders

42 such as inflammatory bowel disease (IBD). Investigations of the host response to individual

43 bacterial species using gnotobiotic animals have led to important insights into the range of immune

44 processes that are fine-tuned by the gut microbiota (Geva-Zatorsky et al., 2017; Sefik et al., 2015a;

45 Tan et al., 2016).

46 Compared with bacteria, the consequences of intestinal colonization by fungi, protozoans, and

47 viruses on the mucosal immune system are less characterized. Eukaryotic viruses occupy a 48 potentially unique immunologic niche. Viruses, by replicating within mammalian cells, alter 49 signaling cascades and membrane-trafficking pathways, are recognized by nucleic acid sensors 50 and the antigen presentation machinery, and often disseminate to other sites as intracellular

51 passengers. Enteric eukaryotic viruses are detected in healthy infant fecal specimens as early as a 52 few days after birth and become increasingly prevalent and diverse during development (Liang et 
al., 2020; Lim et al., 2015). Metagenomics analyses of the viral microbiome (virome) have linked various viruses to intestinal disorders such as IBD (Norman et al., 2015; Nyström et al., 2013; Ungaro et al., 2019). Additionally, both transient and persistent infections precede autoimmunity, as observed with the prolonged presence of enterovirus and the development of type 1 diabetes (T1D) (Vehik et al., 2019; Zhao et al., 2017), suggesting viral exposure has long-term immune consequences.

Our studies with murine norovirus (MNV) indicate that eukaryotic viruses can establish a symbiotic relationship with the host akin to commensal bacteria. Germ-free (GF) or antibiotictreated mice display numerous intestinal defects, including reduced numbers of resident $\mathrm{T}$ cells and susceptibility to chemical injury (Round and Mazmanian, 2009). Inoculation with the persistent MNV strain, CR6, reverses these defects by inducing type I interferon (IFN-I), indicating that an antiviral response can provide developmental cues similar to those attributed to the bacterial microbiota (Kernbauer et al., 2014). Furthermore, colonization by MNV is protective in models of childhood enteric bacterial infections and hospital-acquired opportunistic infections (Abt et al., 2016; Neil et al., 2019). Like symbiotic bacteria, MNV triggers adverse outcomes when introduced into a susceptible background. Th1 cytokines induced by MNV cause disease in animal models of IBD (Basic et al., 2014; Bolsega et al., 2019; Cadwell et al., 2010; Matsuzawa-Ishimoto et al., 2017), and the inflammatory gene expression induced by MNV exacerbates bacterial sepsis (Kim et al., 2011). Similarly, MNV and orthoreovirus strain type 1 Lang (T1L), which causes asymptomatic or mild gastrointestinal infection in humans, induces a Th1 response that triggers the loss of immunologic tolerance to dietary gluten in a mouse model of celiac disease (Bouziat et al., 2017, 2018). Rhesus rotavirus (RRV) accelerates autoimmunity in non-obese diabetic mice following recognition by plasmacytoid dendritic cells (pDCs) (Drescher et al., 2015; Pane and Coulson, 2015). These observations may explain the epidemiological association between related viruses and disease in humans (Axelrad et al., 2018, 2019; Bouziat et al., 2017; Pane and Coulson, 2015).

Despite evidence that eukaryotic viruses in the gut have both beneficial and detrimental effects on the host by influencing immune development, a broader characterization of the immune effects of viral exposure is lacking. Administration of antiviral drugs to conventional mice reduces

82 intraepithelial lymphocyte numbers, cytokine levels, and resilience to intestinal injury through 83 IFN-dependent and -independent mechanisms, suggesting that enteric viruses provide a broad 
84 range of homeostatic cues to the host (Broggi et al., 2017; Liu et al., 2019; Yang et al., 2016).

85 However, the contribution of individual viruses is unclear.

86 Here, we conducted an exhaustive cross-comparison of the host response and colonization

87 dynamics of representative enteric viruses. Almost all the viruses we examined evoked a host

88 response in the absence of disease manifestations, and many displayed enhanced capacity to persist

89 in GF mice. Mono-association experiments revealed long-lasting and specific effects of individual

90 viruses on immune cell populations and gene expression. Comparisons with bacteria-associated

91 mice and studies defining the host response to individual bacterial species revealed overlapping

92 yet distinct consequences of viral exposure. These results provide an overview of the immune

93 space occupied by the enteric virome and highlight the wide range of responses that can occur

94 following asymptomatic viral infection.

\section{RESULTS}

96 Colonization and bacterial dependence of enteric viruses following a natural route of 97 inoculation

98 Studies of viral commensalism are hampered by the lack of established animal models.

99 Established models often involve peritoneal or intravenous inoculation of the virus to circumvent

100 local defenses or employ inhibition of antiviral pathways using knockout mice. Another challenge

101 comes from the capacity of segmented filamentous bacterium (SFB) and murine astrovirus, both

102 of which are widespread in institutional vivaria, to inhibit infections by at least some viruses in the

103 intestine (Ingle et al., 2019; Shi et al., 2019). As such, bacterial or viral microbiota may have

104 prevented investigation of certain viruses. These concerns motivated us to perform a side-by-side

105 comparison of viral burden following oral inoculation of conventional, specific-pathogen-free

106 (SPF) and GF mice with different enteric viruses.

107 We selected a panel of 10 enteric viral strains encompassing six families comprising Groups I,

108 II, III, and IV of the Baltimore classification: two adenoviruses (MAdV1 and 2), an astrovirus

109 (MuAstV), two caliciviruses (MNV CR6 and CW3), a picornavirus (CVB3), two parvoviruses

110 (MVMi and MVMp), and two reoviruses (T1L and RRV). These viruses infect mice, but a detailed

111 time course of infection and corresponding immune response in wild-type C57BL/6 mice

112 following oral inoculation has not been defined for most. Conventional and GF mice inoculated

113 with each virus were monitored for signs of disease and virus in the stool and blood over a 2-month

114 period. We could not recover infectious particles from MNV CW3 at the peak of infection and 
115 found that the contents of stool inhibited detection of infectious viral particles, which prevented 116 the use of plaque assays in all conditions (Fig. S1A). A related concern is that detection of 117 infectious particles may be prone to false-negative results once neutralizing antibodies are

118 produced, especially for blood samples. Therefore, we used qPCR, which is a sensitive assay to 119 monitor viral clearance and facilitate comparisons between viruses. T1L and RRV were exceptions

120 for which we used plaque assays, as the multi-segmented nature of the Reoviridae genome 121 confounds quantification by qPCR.

122 Evidence of disease symptoms, such as diarrhea and hunched posture, were absent in almost all 123 mice, and evaluation of intestinal tissues harvested 28 days post-inoculation (dpi) did not yield 124 evidence of histological abnormalities (Fig. S1B-C). Mice inoculated with CVB3 were the only 125 animals that consistently displayed disease. Despite administering the lowest dose of virus required 126 for seroconversion, 50\% of conventional and GF mice did not survive (Fig. S1D). Considering 127 our focus on commensalism, we excluded CVB3 from subsequent studies. We detected replication 128 of each of the remaining nine viruses in both conventional and GF mice (Fig. 1A-B). Although we 129 were unable to detect RRV in stool or blood, we detected anti-RRV neutralizing antibodies, 130 indicating infection (Fig. 1C). MAdV1, MuAstV, and MVMi genomes were detected in the blood 131 at two or more timepoints. Generally, the presence of these viruses in blood predicted their long132 term detection in stool (30 dpi).

133 Observations made with antibiotic-treated and GF mice indicate the microbiota is required for 134 optimal infection and transmission by certain enteric viruses (Baldridge et al., 2015; Kane et al., 135 2011; Kernbauer et al., 2014; Kuss et al., 2011), which we confirmed for MNV CR6. Surprisingly, 136 most of the other viruses displayed similar or enhanced colonization of GF mice, including the 137 closely related MNV CW3 (Fig. 1A-B and S1E). This apparent contradiction can be explained by 138 a recent study showing that bacterial depletion inhibits MNV CW3 infection in one region of the 139 intestine while promoting viral replication in another (Grau et al., 2020). It also is possible that GF 140 mice are more susceptible to viruses because some aminoglycosides used as antibiotics to deplete 141 bacteria from mice elicit an antiviral IFN-I response (Gopinath et al., 2018). MadV1 and T1L 142 reached higher peak titers in GF mice, but the microbiota did not affect the time to clearance (Fig. $143 \mathrm{~S} 1 \mathrm{E})$. In contrast, MNV CW3, MAdV2, MVMi, and MVMp produced similar peak titers but 144 prolonged viral shedding in the stool (Fig. S1E). MuAstV was not uniformly detectable in the stool 145 of conventional mice, perhaps reflecting pre-existing immunity (Yokoyama et al., 2012), but 
consistently high levels of viral RNA were recovered from GF mice (Fig. 1A-B). Collectively, these data show that exposure to enteric viruses can occur in the absence of overt disease, and many of the viruses chosen for study displayed improved colonization in GF mice. These results, summarized in Table 1, were used to design and interpret the subsequent analysis of the immune response evoked by these viruses.

\section{A reductionist approach to evaluate responses to viral exposure}

To determine whether asymptomatic viral infections are associated with sustained immunological changes, we conducted immune-profiling of mice infected with each virus, a reductionist method similar to that used to define the immunomodulatory activity of individual bacterial species (Geva-Zatorsky et al., 2017; Sefik et al., 2015a; Tan et al., 2016). Although single infections may potentially exaggerate the effect of an individual virus, this approach circumvents concerns about redundancy between viruses in our panel and viral and bacterial members of the microbiota.

We inoculated GF mice perorally with each virus and confirmed infection at 5 dpi. At 28 dpi, six intestinal and extra-intestinal tissues were harvested for analyses by multi-color flow cytometry: colonic and small intestinal lamina propria (cLP and siLP), small intestinal intraepithelial leukocytes (IELs), mesenteric lymph nodes (mLNs), spleen, and lungs. Each sample was analyzed for 32 immune cell subsets based on cell-surface markers and transcription factors. Lymphocyte subsets and functionality were further defined by intracellular staining of six effector cytokines (GRANZYME-B, IL-4, IL-10, IL-17a, IL-22, and IFN- $\gamma$ ) (Fig. S2). Whole colon and small intestine homogenates were subjected to RNA sequencing to examine transcriptional responses. These samples were compared with those prepared in parallel from control GF mice and GF mice colonized with a minimal defined flora (MDF) consisting of a consortium of 15 bacterial strains representing the murine gut microbiota (Brugiroux et al., 2016). These experiments resulted in 462 flow cytometry samples, from which we obtained 21,619 individual immunophenotypes, and 127 transcriptomes.

\section{Enteric viruses promote changes in immune cell populations}

The corresponding fold changes in immune cell populations relative to GF status are shown in Table S1 and the heatmaps in Figure 2A (cLP and siLP) and Figure S3 (IELs, mLNs, lung, and spleen). Viral infection promoted the expansion or contraction of multiple populations, especially in the cLP and siLP. Although each virus had a unique effect, common population changes were 
177 altered in a unidirectional manner; we rarely observed a population that increased with one virus

178 and decreased with another. Viruses were observed to modulate as many immune subsets as MDF

179 bacterial microbiota control (Fig. 2A), suggesting that viruses shape intestinal immune responses.

180 Our results confirmed several anticipated outcomes, substantiating the validity of our approach.

181 We observed a decrease in $\mathrm{CD}^{+}$and $\mathrm{CD} 8^{+}$naïve $\mathrm{T}$ cells $\left(\mathrm{CD} 62 \mathrm{~L}^{+} \mathrm{CD} 44^{-}\right)$and a corresponding 182 increase in $\mathrm{CD}^{+}$and $\mathrm{CD}^{+}$effector memory $\mathrm{T}$ cells (CD62L-CD44 ${ }^{+}$(Fig. 2B-C). We also 183 detected an increase in T-bet ${ }^{+} \mathrm{T}$ cells, indicative of a Th1 response (Fig. 2D) (Szabo et al., 2000). 184 Our screen highlighted an increase of macrophages in the cLP in response to MNV CW3, 185 consistent with effects in conventional mice inoculated with this virus (Winkle et al., 2018). 186 Furthermore, at least three enteric viruses induced an expansion of colonic pDCs (Fig. 2E), a 187 population strongly modulated by the bacterial microbiota (Geva-Zatorsky et al., 2017). Despite 188 this commonality, the overlap between mice inoculated with viruses and MDF was limited. One of the most prominent effects of MDF was the induction of FOXP3-ROR $\gamma \mathrm{t}^{+} \mathrm{CD} 4^{+} \mathrm{Th} 17$ cells, but 190 the effect of viral exposure on this population was negligible (Fig 2A). Instead, we observed an 191 increase of FOXP3 ${ }^{+} \mathrm{CD}^{+}{ }^{+}$T cells (Tregs) by MVMi in the cLP (Fig. 2F) and by T1L and MAdV1 192 in the siLP (Fig. 2G). The absence of ROR yt within this population (Fig. 2A) suggests that these 193 Tregs are distinct from bacterial-induced peripheral Tregs (Sefik et al., 2015b).

194 We used hierarchical clustering to define the relative similarity of the overall immune cell composition between conditions (Fig. 2H-I). In both cLP and siLP, MDF was in a clade distinct 196 from individual viruses and the GF control. Viruses did not segregate based on taxonomical 197 relationships, suggesting the immunomodulatory properties observed were marginally intrinsic to 198 a viral family or genus. To quantify how virus-associated variables can explain the variance 199 observed between samples, we conducted a distance-based redundancy analysis (db-RDA) based 200 on shared characteristics (Table 1): genome type (DNA versus RNA), the capacity to persist in the 201 host, defined as detectable virus $30 \mathrm{dpi}$ in blood or stool (persistence), and detectable virus in blood 202 (viremia). We included the identity of the virus (identity) as a benchmark variable in this analysis. 203 Indeed, identity was the major explanatory variable, which alone accounted for almost $25 \%$ of the 204 variance, supporting the conclusion that individual viruses promote substantially distinct 205 immunomodulatory outcomes (Fig. 2J-K). The second strongest explanatory variable was genome 206 type, although the effect size was modest. The combined effect size of the genome, persistence, 207 and viremia variables left much of the variance unexplained, indicating that differences in immune 
responses to these viruses are likely due to complex interactions between each virus and the host.

Among the other tissue compartments examined, mLNs and lungs displayed the greatest changes in immune cells following viral infection (Fig. S3). Like the intestinal lamina propria, we observed, to a lesser extent, a decrease in naïve and an increase in effector memory $\mathrm{CD}^{+}$and

$212 \mathrm{CD}^{+} \mathrm{T}$ cells in the lungs. Together, these data indicate that enteric viruses influence the immune 213 cell composition of a naïve host, much of which is virus strain-specific. Even for non-persistent 214 viruses, alterations in immune cell frequencies were observed in mice long after the last time point 215 in which viral nucleic acid was detectable.

\section{Enteric viruses increase cytokine production by immune cells}

217 In parallel with the above analyses, we assessed cytokine production following PMA218 ionomycin stimulation of single cell suspensions from each tissue (Fig. 3A, S4A, and Table S1). 219 Inoculation with several viruses led to an increase in cLP T cells producing the Th1 cytokine, IFN$220 \gamma$ (Fig. 3B), which correlated with the increase in T-bet ${ }^{+}$lymphocytes (Fig. S4B). The increase in


regenerative cytokine that mediates the protective effect of MNV in models of intestinal injury and bacterial infection (Abt et al., 2016; Neil et al., 2019). Most viruses enhanced IL-22 production

224 by a variety of cLP and siLP lymphoid cells including CD4 ${ }^{+} \mathrm{T}$ cells, $\gamma \delta^{+} \mathrm{T}$ cells, and ILCs (Fig. 3A). Quantification of total IL-22 $2^{+}$cells using an inclusive $\mathrm{CD}_{4} 5^{+}$gate in our profiling protocol indicated that cLP infected by six of the viruses and siLP infected by five of the viruses increased the total proportion of IL-22-producing cells (Fig. 3C-D). This IL-22 production by CD45 ${ }^{+}$cells 228 correlated with the proportion of granulocytes and mononuclear phagocytes in the cLP (Fig. S4C).

229 The increase in IL-22+ cells was evident in mice that were inoculated with non-persistent viruses, 230 most notably T1L, indicating that alterations in the function of immune cells can be sustained long 231 after the virus is below the threshold of detection (Fig. 3A).

232 Although we did not observe common changes in the capacity to produce cytokines in other 233 tissue compartments as we observed for IL-22 in the lamina propria, we noted several changes in 234 the proportion of cytokine-producing immune cells that were virus strain-specific (Fig. S4A). As 235 an example, IFN- $\gamma^{+} \mathrm{IL}-10^{+} \mathrm{CD}^{+} \mathrm{T}$ cells ( $\mathrm{Tr} 1$ cells), a T-helper subset with regulatory functions 236 (Häringer et al., 2009), was increased in mice infected with persistent MNV strain CR6 in cLP and $237 \mathrm{mLN}$ (Fig. 3E-F).

238 Hierarchical clustering of cytokine production in cLP and siLP cells showed that virus-infected 
mice did not form clades independent of GF and MDF mice as obviously as they did when analyzing immune cell populations based on cell-surface markers and transcription factors (Fig. 3G-H). As with the prior analyses, viruses from the same families did not uniformly cluster together, and the major explanatory variables for cytokine production were identity, followed by genome (Fig. 3I-J). Together, these results indicate that virus-infected mice display increases in cytokine-producing immune cells that are both common and virus-strain specific.

\section{Intestinal transcriptome of virus-infected mice}

Of genes profiled in the colon and small intestine, 497 and 355, respectively, displayed differential expression (DE) in at least one virus-infection condition compared with GF mice ( $\geq 2$ fold, $p$ value $\leq 0.01$ ) (Fig. 4A-C, Table S2A-B). In comparison, 146 and 92 genes in the colon and small intestine displayed differential expression in MDF-colonized mice and minimally overlapped with the virus-induced expression changes (Fig. 4D-E, Table S2C-D). Gene ontology (GO) analyses showed that viral infection influenced a wide range of immune-related pathways, especially in the colon (Fig. 4F-G). Viral infection was associated with antiviral immunity pathways, such as defense response to virus and cellular response to interferon-beta. The enrichment for genes associated with IFN- $\gamma$ is consistent with the flow cytometry data identifying a Th1 response. Both MDF and viruses were associated with B cell activation and bacterial response pathways. The enrichment of DE genes involved in metabolic processes was specific to MDF, perhaps reflecting the nutrient exchange between host and bacteria.

Permutational multivariate analysis of the variance after principal component analysis (PCA) confirmed that the transcriptional responses to viruses differed significantly from that of GF and MDF conditions and that each virus induced a distinct gene expression pattern (Fig. 4H-I and S5AB). The major explanatory variables of the variance between samples were again identity followed by genome (Fig. 4J-K). Because much of the transcriptome variance was unexplained, we determined whether the immune cell composition and cytokine production (described in Figs. 2 and 3) correlated with differences in gene expression between conditions. DC and T cell subsets were major explanatory variables and included cell types with recognized functions in antiviral responses such as Tbet $^{+} \mathrm{CD}^{+} \mathrm{T}$ cells and pDCs (Fig. 4L). Among the cytokines tested, only IL22 was a significant explanatory parameter (Fig. S5C), likely reflecting the role of this cytokine in coordinating antimicrobial gene expression (Keir et al., 2020). Collectively, these results correlate 
underscoring the importance of investigating the immune effects of individual virus strains, which cannot be predicted based on taxonomic features alone.

\section{2}

\section{Intestinal gene expression common and specific to individual viruses}

273 We next identified specific genes and pathways associated with each virus individually and 274 those in common. We observed 15 and three differentially regulated genes in the colon and small intestine, respectively, that were shared by at least half of the viruses studied, including immunoglobulin genes Igha, Igkc, Iglc1, Jchain, and Pou2afl (Fig. 5A-B). This finding is consistent with the increased expression of genes associated with B cell activation (Fig. 4F-G) as well as previous findings that MNV CR6 enhances local and systemic antibody production in GF mice and that IgA production is frequently observed during enteric viral infections (Blutt and Conner, 2013; Kernbauer et al., 2014).

Increased expression of antimicrobial genes is a hallmark of intestinal colonization by symbiotic bacteria (Geva-Zatorsky et al., 2017; Hooper et al., 2001). We examined expression of antimicrobial genes during viral infection by constructing an antimicrobial gene set in which genes annotated in GO:0050829 (defense response to Gram-negative bacterium), GO:0050830 (defense response to Gram-positive bacterium), and GO:0061844 (antimicrobial humoral immune response mediated by antimicrobial peptide) were pooled. Expression of numerous antimicrobial genes was increased in virus-infected mice compared with GF controls $(\geq 1.5$-fold change, $p \leq 0.01)$ (Fig. 5C-D). However, the overall response was not as strong as that induced by MDF. Nonetheless, there were transcripts induced exclusively by viruses, including mannose-binding protein $\mathrm{C}(M b l 2)$ and the interferon-inducible GTPases, Iigp1, Irgm2, and Gbp2.

MNV CR6 but not MNV CW3 fortifies the intestinal barrier by inducing a local IFN-I response (Kernbauer et al., 2014; Neil et al., 2019). IFN-I (IFN- $\alpha$ and - $\beta$ ) and type III interferon (IFN- $\lambda$ ) are 293 antiviral cytokines produced in response to viral nucleic acid that evoke a similar set of interferon-

294 stimulated genes (ISGs), which we collectively term here as an "IFN signature". Consistent with 295 our previous findings, colonization with MNV CR6 but not MNV CW3 was associated with an 296 IFN signature (Fig. 5E). Surprisingly, no other virus from our panel yielded an IFN signature, 297 despite high levels of viral nucleic acid produced by some of them, such as MuAstV. Moreover, 298 only MNV CR6 was associated with increased transcription of ISG regulators (Fig. 5F). We 299 confirmed that expression of representative ISGs Isg15, Ifit1, and Oasla was increased only in 300 mice colonized with MNV CR6 (Fig. S6A). 
In contrast to IFN-I, IL-22 should regulate expression of DE genes for multiple viruses based on its effect size on transcriptional variance (Fig. S5C). To test this prediction, we used Gene Set Enrichment Analysis (GSEA) to determine whether transcripts altered in the intestine of $I l-22^{-/-}$ mice (Gronke et al., 2019) were differentially regulated in virus-infected mice. This analysis confirmed that most virus-infected mice produced an IL-22 signature. (Fig. S6B-C).

We used Ingenuity Pathway Analysis (IPA) to identify additional regulators in the following categories: cytokine, ligand-dependent nuclear receptor, transmembrane receptor, transcript regulator, and other. In the colon, four viruses were associated with such regulators. IFN-related factors were the main regulators associated with MNV CR6, whereas MuAstV, MVMp, and T1L upregulated other pathways (Fig. 5G). PRDM1, also known as BLIMP1, is a regulator of terminal B-cell differentiation (Shaffer et al., 2002) and influenced transcriptional responses to MuAstV and T1L, supporting a role for viruses in B cell development. The association of MuAstV and macrophage differentiation factor CSF-1 is consistent with the observation that MuAstV-colonized mice displayed an increase in cLP macrophages (Fig. 2A). In the small intestine, genes induced by pro-inflammatory cytokines such as IL- $1 \beta$, IFN- $\gamma$, and TNF- $\alpha$ were enriched in mice infected with either MVMi or RRV (Fig. 5H). Other factors identified by this approach have been implicated in immunity in some settings. For example, insulin (Ins1), which was associated with MVMi infection, is involved with IFN- $\gamma$ in a feedback loop to promote the effector $\mathrm{CD}^{+} \mathrm{T}$ cell response to murine cytomegalovirus infection (Šestan et al., 2018). Therefore, in addition to the classic ISGs downstream of IFN-I that we observe for MNV CR6, viral exposure induces the expression of genes regulated by a range of signaling molecules and pathways required for mucosal immunity.

Intestinal transcriptomes of virus-infected mice are enriched for bacterial microbiome gene signatures

We used a GSEA strategy analogous to a previously described approach (Godec et al., 2016) to compare the transcriptome of virus-infected mice with gene-expression signatures of mice monocolonized with 53 individual species of the bacterial microbiota (Geva-Zatorsky et al., 2017)

327 (Fig. 6A-D, Table S3). Colonic transcripts of MDF-colonized mice in our study were positively 328 enriched for genes upregulated in microbiota-replete conditions (conventional SPF mice) (Geva329 Zatorsky et al., 2017), indicating concordance in the positive controls (Fig. 6A). Similarly, the 330 small intestinal transcriptome of MDF-colonized mice displayed a negative enrichment score for 331 genes downregulated in conventional SPF mice (Fig. 6D). Twenty of the 53 bacterial species 
332 displayed a relationship with one or more viruses using this approach. We identified 91 virus-

333 bacterium pairs, with 60 displaying the same directionality of regulation (i.e., positive enrichment

334 of upregulated bacterial gene sets in virus-associated transcripts and negative enrichment of 335 downregulated bacterial gene sets in virus-associated transcripts) (Fig. 6A-D). Certain bacterial 336 gene sets displayed exclusive pairing with one virus, as observed with several Bacteroides and

337 Parabacteroides species and T1L in the colon. This consistent pairing between T1L and the 338 Bacteroidales order suggests that this virus induces a similar reaction to colonization by this 339 prototypical group of commensal bacteria. The MNV CR6-induced gene set also was paired with 340 multiple bacterially upregulated gene sets in the colon. We observed a particularly strong 341 enrichment for the Enterococcus faecalis signature, a facultative anaerobic bacterium of the 342 Enterococcaceae family (Fig. 6E).

343 Lastly, we compared our intestinal flow cytometry data with results gathered using mice 344 monocolonized with bacteria (Geva-Zatorsky et al., 2017). Due to differences in gating strategies 345 and markers used to identify cell types, we restricted our comparison to 16 immune cell subsets 346 that were quantified in a similar manner across the datasets (Table S4). Hierarchical clustering 347 using the z-scores of the two datasets indicated that the GF groups from both datasets clustered 348 together, as did MDF from our study and SPF from Geva-Zatorsky et al (Fig. 6F-G). Most bacteria 349 and viruses clustered together with GF or in neighboring clades distinct from MDF and SPF, 350 suggesting the contribution of a specific bacterium or virus, when present alone, accounts for only 351 a modest fraction of the total microbiota-dependent effects on immune cell composition. The 352 viruses were interspersed among bacteria rather than clustered together in a single clade, indicating 353 that virus-induced changes to immune cell frequencies does not reflect a uniform immunological 354 response to viruses distinct from that evoked by bacteria.

\section{DISCUSSION}

In this study, we investigated whether asymptomatic or subclinical infections of the gastrointestinal tract by eukaryotic viruses shape the mucosal immune system, as has been demonstrated for numerous bacterial members of the microbiota (Honda and Littman, 2012; Round and Mazmanian, 2009). Only one of the 10 viruses chosen for study led to illness or death,

360 allowing us to define the immune effects of nine viruses in the absence of disease.

In the process of establishing virus infection models, we made several observations about the dynamics of infection. First, we found that nucleic acid of several viruses remains detectable in 
stool or blood for a prolonged interval. Unlike retroviruses and herpesviruses, members of these viral families are not known to establish latency. Observations with measles virus infections indicate that viral antigens and RNA can persist, even for viruses that do not establish latency or integrate DNA copies into the host genome (Griffin, 2020). For some viruses, this type of persistence could be mediated by immune evasion, as proposed for MNV (Lee et al., 2019; Tomov et al., 2017). Regardless of the mechanism, we found that the microbiota had a strong effect on persistence. While antibiotic treatment hinders infection by some enteric viruses (Baldridge et al., 2015; Kernbauer et al., 2014; Kuss et al., 2011), our data showed that not all viruses benefit from the presence of bacteria. An important future goal is to determine whether this resistance to infection displayed by conventional mice reflects the presence of specific autochthonous viruses or bacteria in the gut (Ingle et al., 2019; Shi et al., 2019).

Our flow cytometric and transcriptional analyses were well correlated and support the hypothesis that asymptomatic colonization by enteric viruses has consequences for the host. Although each virus was associated with a unique immune profile following oral inoculation of GF mice, there were a few recurrent themes. Viral infection generally promoted the differentiation of lymphocytes, specifically maturation of T cells and Th1 polarization. Laboratory mice display deficiencies in mature $\mathrm{T}$ cells due to the absence of exposure to infectious agents while housed in SPF conditions (Beura et al., 2016; Lin et al., 2020; Yeung et al., 2020). In this context, it is notable that wild mice and pet-shop mice, which have a more mature lymphocyte compartment, are seropositive for viruses closely related to those in our panel (adenovirus, MNV, parvovirus, reovirus, and rotavirus) (Beura et al., 2016). These common enteric viruses may contribute to immune maturation in the natural environment.

We find it noteworthy that the immune effects of a given virus could not be explained by qualitative features alone. Closely related viral strains evoked distinct responses in most of the parameters we assessed. The nucleic acid composition of the viral genome (DNA versus RNA) contributed modestly but reproducibly to the variance, whereas viral dissemination and persistence did not appear to explain differences between conditions. Accordingly, one remarkable finding was that changes to immune cells and gene expression patterns were readily observed in mice in which viral nucleic acid was no longer detectable. If this sustained effect of viruses translates to

392 humans, then cross-sectional metagenomics studies of patient cohorts would miss potentially meaningful exposures to viruses that occurred prior to disease onset. Longitudinal virome analyses 
394

395

396

397

of children genetically susceptible to T1D identified an inverse relationship between early life adenovirus and circovirus exposure with subsequent appearance of serum autoantibodies (Vehik et al., 2019; Zhao et al., 2017). Thus, we advocate prospective and longitudinal sampling for virome-association studies when possible.

Based on our prior studies with MNV, we anticipated that at least some virus-infected mice would display an IFN signature. Instead, we observed an increase in IL-22-producing cells and an IL-22-mediated gene-expression pattern following infection by several of the viruses in our panel. IL-22 functions in intestinal homeostasis and expression of antimicrobial genes (Gronke et al., 2019; Keir et al., 2020). We think it possible that IL-22 induction offsets damage caused by enteric viruses, thereby facilitating a commensal relationship.

A comparison between our results and an analogous dataset gathered using bacterial monocolonization identified virus-bacterium pairs that stimulate overlapping responses by the host. For example, E. faecalis and MNV CR6 shared a colonic gene expression signature, which increased our confidence in the approach because these two infectious agents also share the capacity to confer protection in the DSS model of intestinal injury (Kernbauer et al., 2014; Neil et al., 2019; Takahashi et al., 2019; Wang et al., 2014). Several of the bacteria that evoke an immune response overlapping with viruses are implicated in disease, such as Ruminococcus gnavus and Bacteroides vulgatus in IBD (Hall et al., 2017; Png et al., 2010; Rath et al., 1999). It will be interesting to test the role of the matching viruses in animal models in which disease is dependent on these bacteria (Bloom et al., 2011; Ramanan et al., 2014, 2016; Yu et al., 2020).

Our survey was restricted to a limited number of viruses and, therefore, we were not able to capture the vast diversity of viruses found in humans. Unlike bacteria isolated from the human gut, which almost always colonize GF mice, many medically important viruses display narrow species tropism or altered virulence when inoculated into mice. A broader survey of viruses will likely identify additional cell types and pathways influenced by viral infection. Another limitation is that we chose a single-infection approach to identify direct responses and avoid missing immune effects that overlap with the existing microbiota. This approach also enabled our in-silico comparison of virus-induced immune responses with those induced in mice monocolonized with bacteria.

We envision two situations in which our results can guide studies investigating how the enteric virome modulates immunity in the presence of bacteria. First, mice associated with defined flora 
can be used to assess the immune effects of individual bacteria within a complex community (Fischbach, 2018). This synthetic ecology approach could incorporate viruses with immunogenic potential from our panel to better reflect the complexity of the real-world microbiome. Second, we advocate testing the role of these and other viruses in animal models of inflammatory diseases, many of which are thought to be dependent on bacterial members of the microbiota. Although the Th1 response to MNV CR6 is inconsequential in wild-type C57BL/6 mice, mutation of IBDsusceptibility gene ATG16L1 sensitizes the intestinal epithelium to the otherwise subtle effect of viral infection (Cadwell et al., 2010; Matsuzawa-Ishimoto et al., 2017). Observations in studies of MNV-infected mutant mice allowed us to identify homeostatic mechanisms involved in barrier integrity that are conserved in humans (Cadwell et al., 2008; Matsuzawa-Ishimoto et al., 2020). Thus, incorporating viruses into genetic disease models can reveal vital pathways that promote health.

Our findings indicate that eukaryotic viruses in the gut have unappreciated immunomodulatory capacity in addition to well-recognized roles as causative agents of gastroenteritis. The reaction to viral infection could be beneficial in the appropriate setting, as demonstrated by proof-of-principle experiments showing that MNV and MuAstV strains administered prophylactically protect mice from enteropathogenic E. coli (Cortez et al., 2020; Neil et al., 2019). There is precedent for manipulation of the gut virome for therapeutic purposes. Oral poliovirus vaccine provides cross-

443 protection against other pathogens, which has been used as a rationale to administer this attenuated

444 virus instead of inactivated vaccine in polio-endemic regions (Upfill-Brown et al., 2017). Our 445 ongoing studies using animal models will enable future safety and efficacy assessments of viromebased interventions.

\section{ACKNOWLEDGMENTS}

We wish to thank Dr. Julie Pfeiffer (UT Southwestern), Dr. Jason G. Smith (University of Washington), Dr. David Pintel (University of Missouri), Dr. Peter Tattersall (Yale University), Dr. Harry B Greenberg (Stanford University), and Dr. Kathy McCoy (University of Calgary) for sharing reagents with us and providing advice regarding culturing techniques. We wish to thank the NYU Grossman School of Medicine Flow Cytometry and Cell Sorting, Microscopy, Genome

454 in part by National Institutes of Health $[\mathrm{NIH}]$ grants P31CA016087, S10OD01058, and 
456 technical assistance with gnotobiotics. This research was supported by NIH grants DK093668 457 (K.C.), AI121244 (K.C.), HL123340 (K.C.), AI130945 (K.C.), R01 AI140754 (K.C.), F31 458 DK108562 (J.J.B.), T32 HL007751 (J.J.B.), R01 AI038296 (T.S.D.), R01 DK098435 (T.S.D.), 459 and a pilot award from the NYU Cancer Center grant P30CA016087 (K.C.). Additional support 460 was provided by the Faculty Scholar grant from the Howard Hughes Medical Institute (K.C.), 461 Crohn's \& Colitis Foundation (K.C.), Merieux Institute (K.C.), Kenneth Rainin Foundation (K.C.), 462 Judith \& Stewart Colton Center of Autoimmunity (K.C.), and the Heinz Endowments (T.S.D.). 463 K.C. is a Burroughs Wellcome Fund Investigator in the Pathogenesis of Infectious Diseases.

\section{AUTHOR CONTRIBUTIONS}

465 S.D. and K.C. conceived the study and designed the experiments. S.D. performed, analyzed, 466 and interpreted all the experiments. T.H. and A.R.V. helped perform the viral colonization 467 experiments. J.A.N. helped design and interpret data regarding MNV. S.Y.W. prepared the 468 minimal defined flora. J.J.B., K.U., and T.S.D. provided the T1L virus and helped design T1L 469 detection method. K.C. oversaw analysis and interpretation of all experiments described. S.D. and 470 K.C. wrote the manuscript with inputs from all the authors.

\section{DECLARATION OF INTERESTS}

472 K.C. receives research funding from Pfizer and Abbvie. K.C. has consulted for or received an 473 honorarium from Puretech Health, Genentech, and Abbvie. K.C. has provisional patents, U.S. 474 Patent Application. No. 15/625,934 and 62/935,035. 
bioRxiv preprint doi: https://doi.org/10.1101/2020.10.20.347286; this version posted October 20, 2020. The copyright holder for this preprint (which was not certified by peer review) is the author/funder, who has granted bioRxiv a license to display the preprint in perpetuity. It is made available under aCC-BY-NC-ND 4.0 International license.
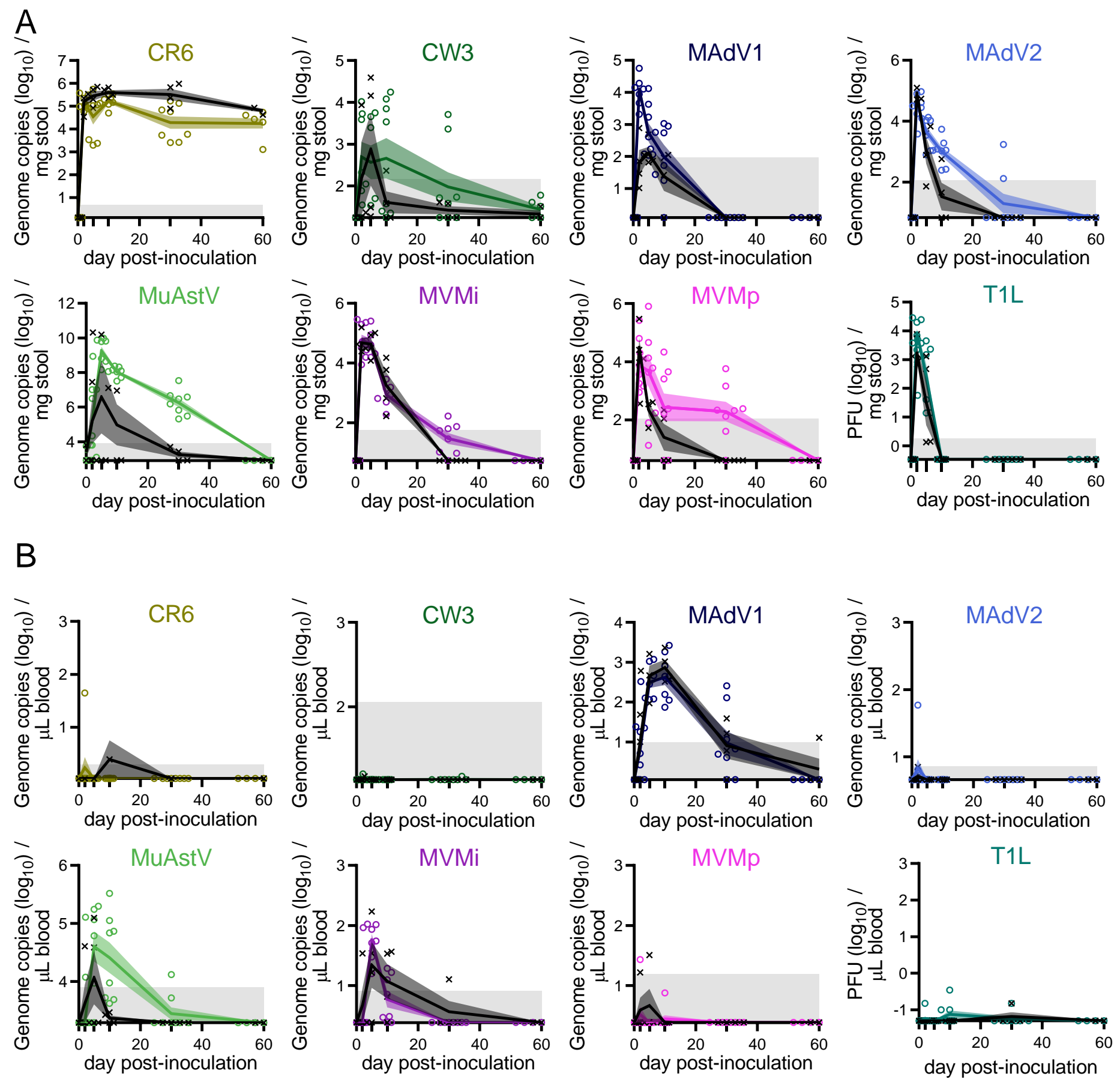

\section{C}

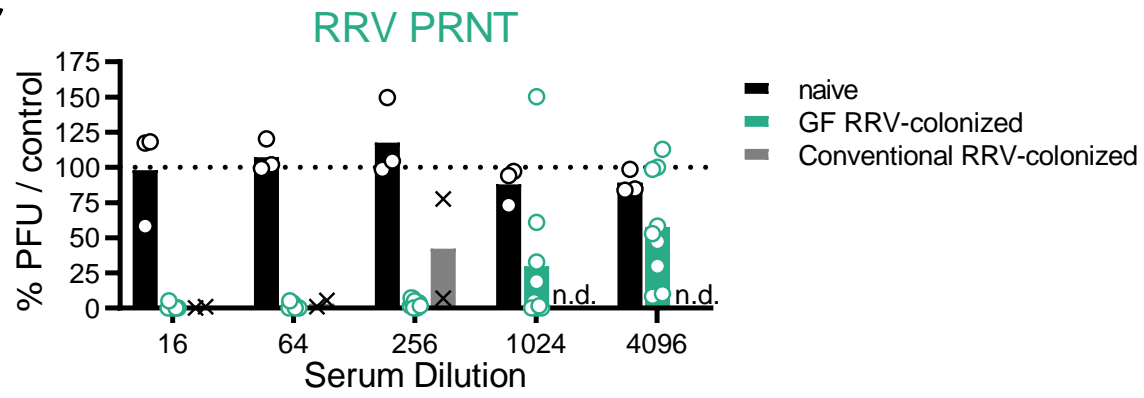

Figure 1 


\section{Figure 1. Colonization and Bacterial Dependence of Enteric Viruses Following the Natural}

\section{Route of Infection}

477 (A-B) Stool (A) and blood (B) were collected at the timepoints shown from conventional (black)

478 and GF mice (colored) inoculated with the virus shown. Viral titers were quantified by plaque

479 assay or qPCR. Symbols indicate individual samples. Lines pass through the mean at each

480 timepoint. Shadowed areas indicate the SEM. Gray areas indicate the limit of detection. $\mathrm{N}=4-8$

481 mice per condition, combined from two independent experiments.

482 (C) Neutralizing antibodies in the sera of mice 28 days post-inoculation (dpi) inoculated with RRV

483 were quantified by a plaque-reduction neutralization assay. Reduction in plaque-forming units

484 (PFU) is shown as percent relative to control sera from naïve conventional mice. Results are from

485 3-9 mice from three independent experiments. n.d.: not determined. 

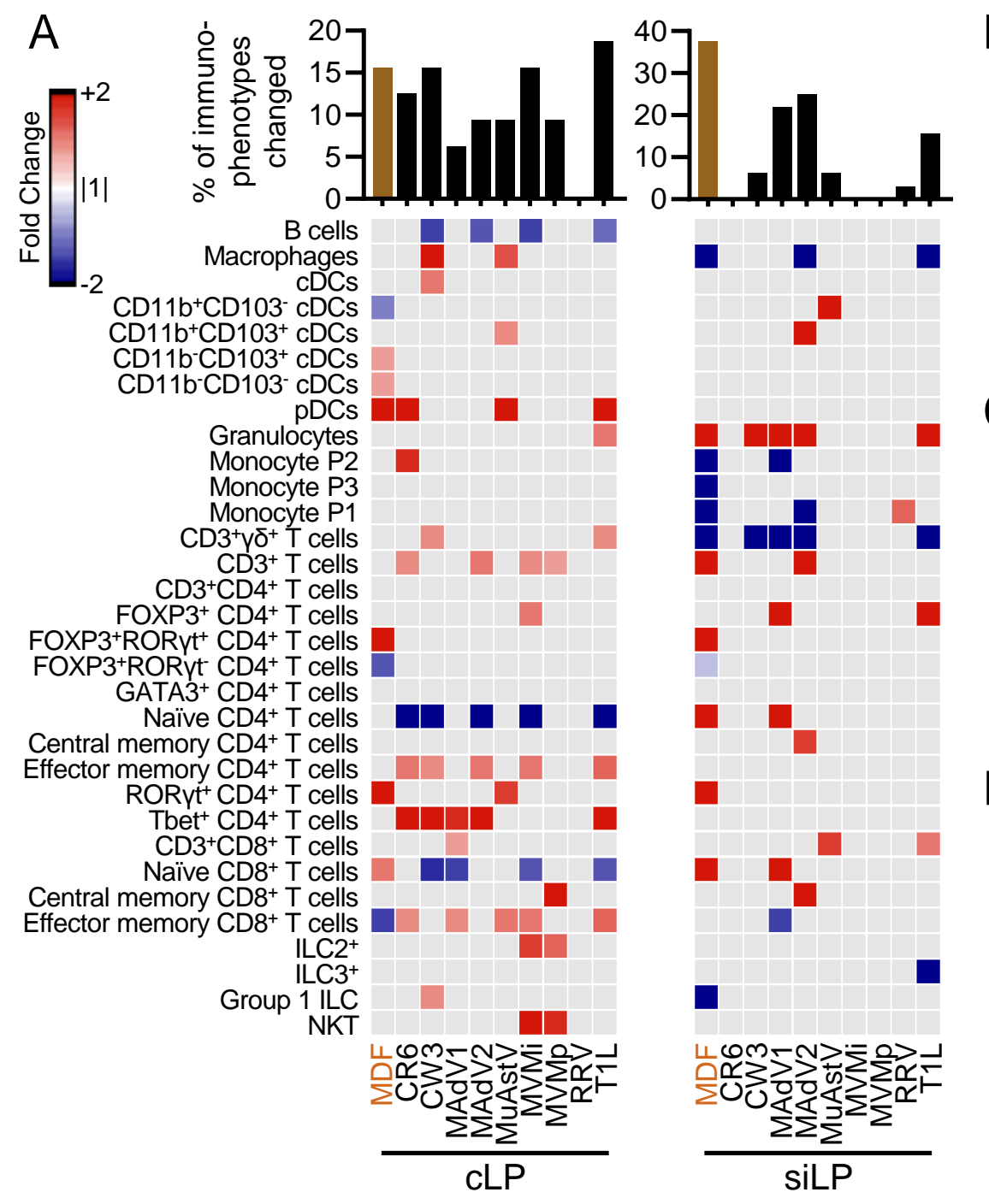

$\mathrm{H}$
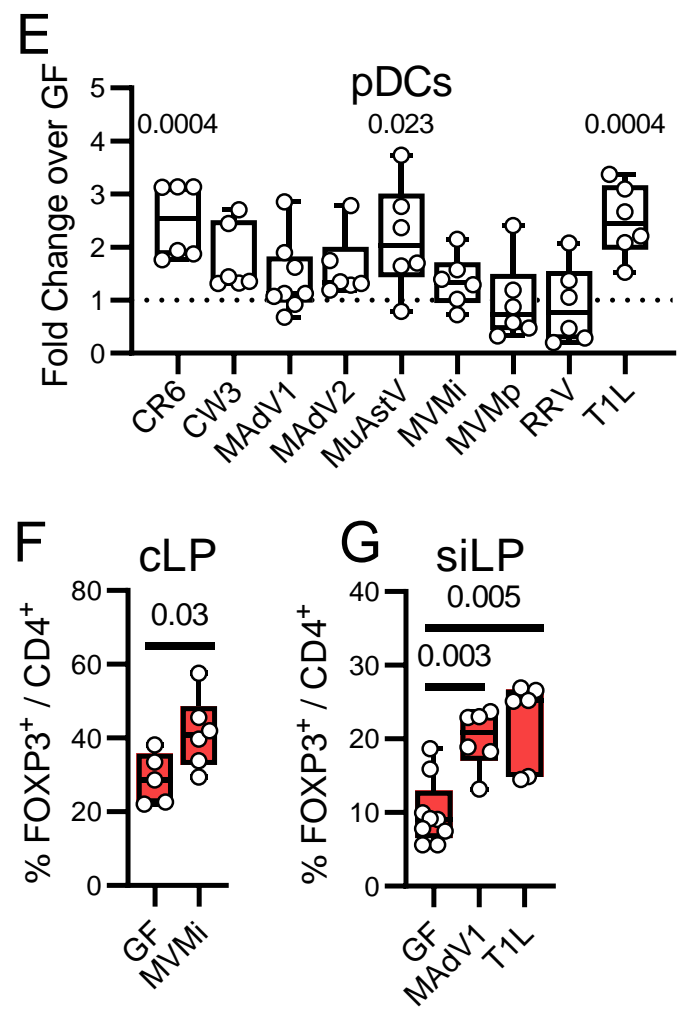

$\mathrm{B}$

$\square$ CD4 $\square$ CD8
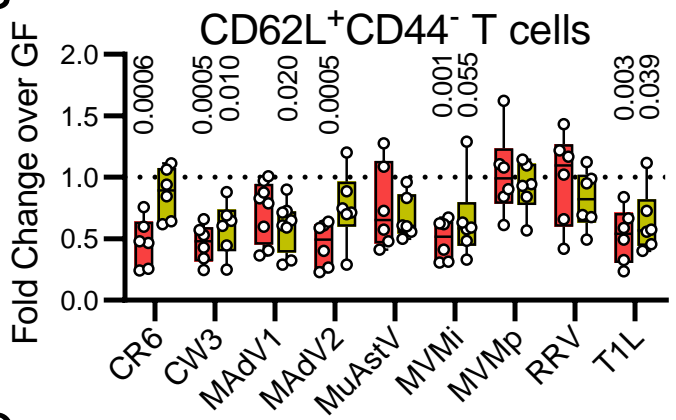

C

CD62L'CD44 ${ }^{+} \mathrm{T}$ cells

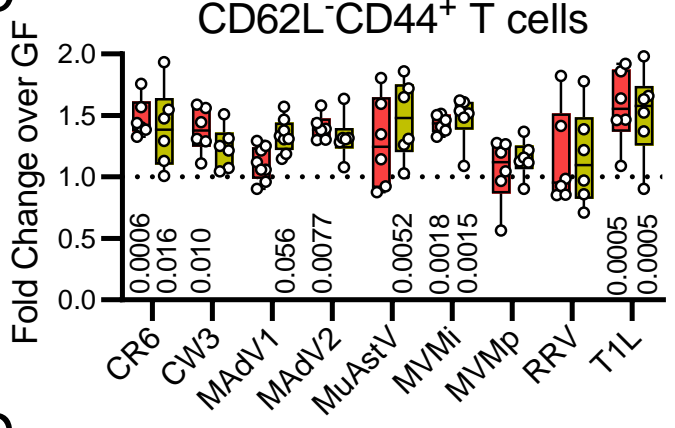

$\mathrm{D}$

$\left.\begin{array}{ll}\hline & 0 \\ 0 & 6\end{array}\right]<0.001 \quad \begin{gathered}\text { T-bet } \\ <0.001\end{gathered}$

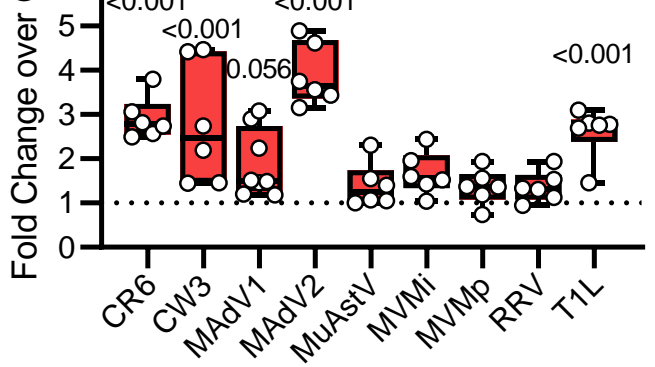

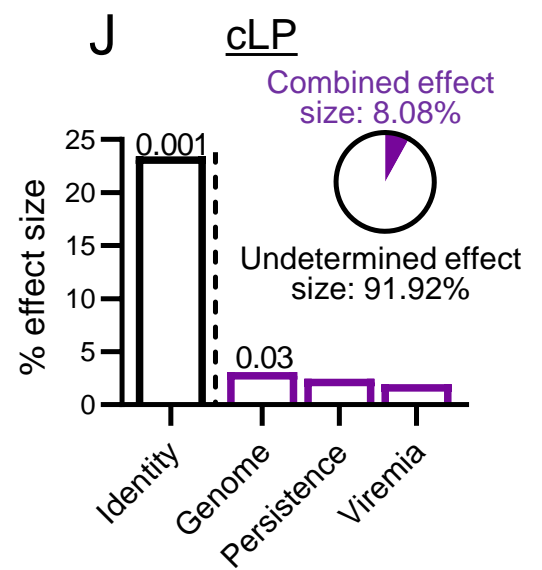

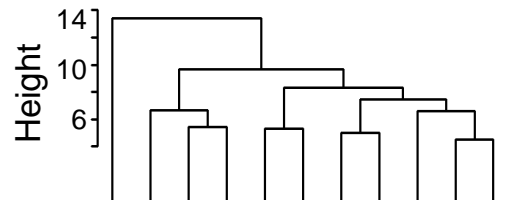

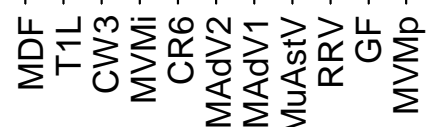

J $\quad \underline{C L P}$

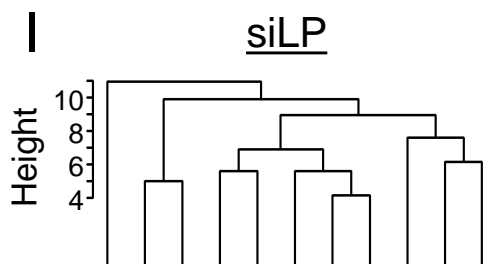

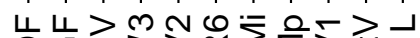

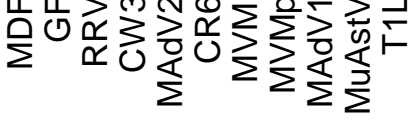

K siLP

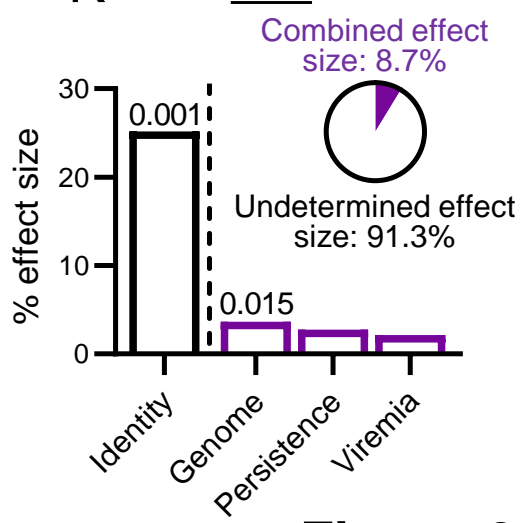

Figure 2 


\section{Figure 2. Enteric Viruses Promote Changes in Immune Cell Populations}

487 (A) Heatmap showing average fold-change for cLP and siLP immune populations identified by

488 flow cytometry (using the gating strategy in Fig. S2) for mice inoculated with individual viruses

489 or MDF relative to GF controls with an FDR $<0.1$. Gray: FDR $>0.1$. Bar graph on top represents

490 the proportion of immune populations with an FDR $<0.1$ and a fold change $>1.5$.

491 (B-E) Fold changes of CD62L ${ }^{+} \mathrm{CD}_{4}^{-}(\mathrm{B}), \mathrm{CD}^{-} \mathrm{L}^{-} \mathrm{CD} 44^{+}(\mathrm{C})$, T-bet $^{+}$(D), and pDCs (E) in the

$492 \mathrm{cLP} \mathrm{CD}^{+}(\mathrm{B}-\mathrm{D}), \mathrm{CD}^{+}(\mathrm{B}-\mathrm{C})$, or $\mathrm{CD}^{+} 5^{+}(\mathrm{E})$ populations. Each dot represents a single sample.

493 (F-G) Percentage of Foxp3 ${ }^{+}$cells in the cLP (F) or siLP (G) CD4 ${ }^{+}$populations. Each dot represents 494 a single sample.

495 (H-I) Hierarchical clustering of the different conditions based on cLP (H) and siLP (I) population 496 frequencies.

497 (J-K) Effect size determined by db-RDA of viral characteristics: identity, genome, persistence, and 498 viremia as explanatory variables of the cLP (J) and siLP (K) population frequency variance. Pie 499 charts represent the combined effect size of genome, persistence, and viremia.

500 Statistical significance was calculated by one-way ANOVA followed by Dunn's post-hoc analysis 501 and corrected for multiple testing by the Benjamini-Hochberg procedure (A-E) or by non502 parametric Mann-Whitney test (F-G). 
bioRxiv preprint doi: https://doi.org/10.1101/2020.10.20.347286; this version posted October 20, 2020. The copyright holder for this preprint (which was not certified by peer review) is the author/funder, who has granted bioRxiv a license to display the preprint in perpetuity. It is made available under aCC-BY-NC-ND 4.0 International license.

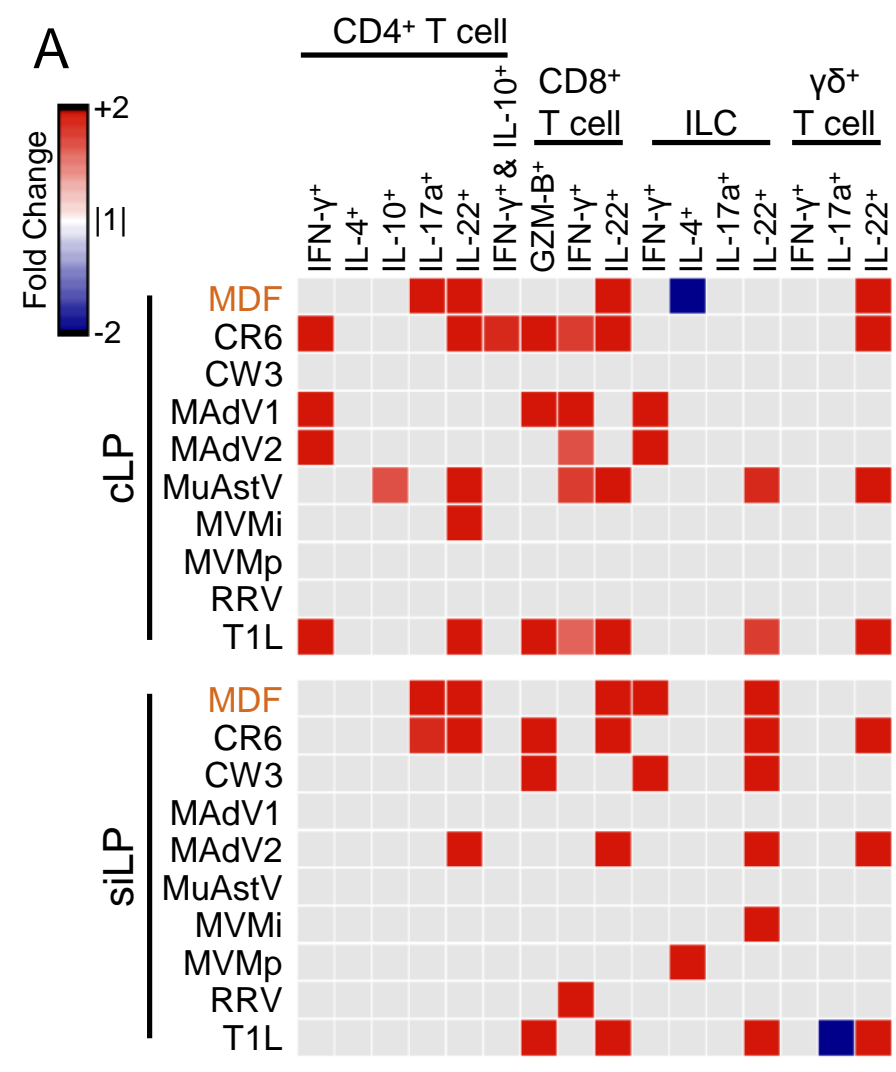

B CD4 $\square$ CD8

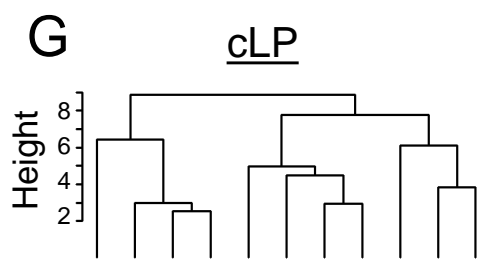

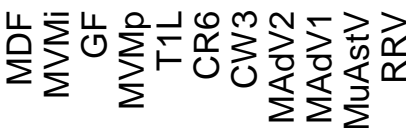

$\mathrm{H} \quad \underline{\text { siLP }}$

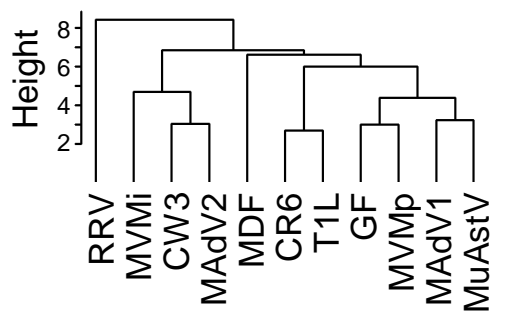

$1 \quad \underline{\mathrm{CLP}}$
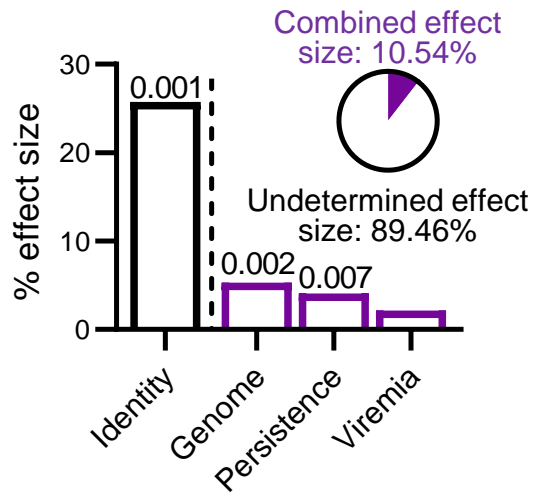

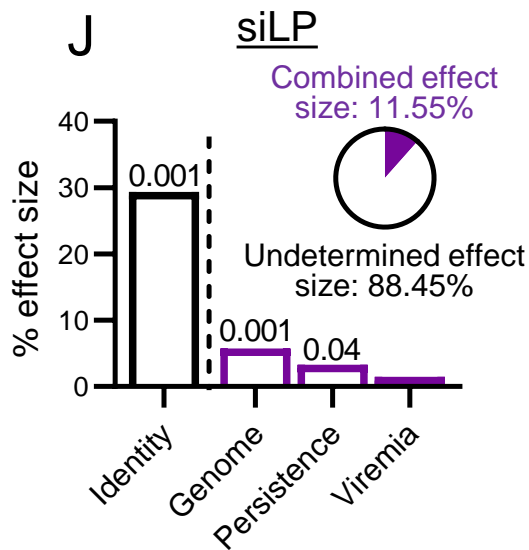

Figure 3 


\section{Figure 3. Enteric Viruses Increase Cytokine Production by Immune Cells}

504 (A) Heatmaps showing average fold-change for cytokine-producing immune cells in cLP and siLP

505 identified by flow cytometry for mice inoculated with the viruses shown or MDF relative to GF

506 controls with an FDR<0.1. Gray: FDR $>0.1$.

507 (B-D) Fold-changes of IFN- $\gamma^{+}(\mathrm{B})$ and $\mathrm{IL}^{-22^{+}}$(C-D) cells in the cLP CD4 ${ }^{+}$and CD8 ${ }^{+}(\mathrm{B})$, cLP

$508 \mathrm{CD} 45^{+}(\mathrm{C})$, and siLP CD45 ${ }^{+}(\mathrm{D})$.

509 (E-F) Representative dot plot (E) and percentage of IFN- $\gamma^{+} \mathrm{IL}-10^{+}$cells in the cLP CD4 ${ }^{+}$T cell 510 population $(\mathrm{F})$.

511 (G-H) Hierarchical clustering of the different microbial associations based on the cLP (G) and

$512 \operatorname{siLP}(\mathrm{H})$ cytokine production frequencies.

513 (I-J) Effect size determined by db-RDA of virus as explanatory variables of the cLP (J) and siLP

514 (K) cytokine-producing immune cell frequency variance. Pie charts represent the combined effect

515 size of genome, persistence, and viremia.

516 Statistical significance was calculated by one-way ANOVA followed by Dunn's post-hoc analysis

517 and corrected for multiple testing by the Benjamini-Hochberg procedure (A-B), by Kruskal-Wallis

518 test followed by Dunn's post-hoc analysis (C-D), or by non-parametric Mann-Whitney test (F). 
bioRxiv preprint doi: https://doi.org/10.1101/2020.10.20.347286; this version posted October 20, 2020. The copyright holder for this preprint (which was not certified by peer review) is the author/funder, who has granted bioRxiv a license to display the preprint in perpetuity. It is made available under aCC-BY-NC-ND 4.0 International license.

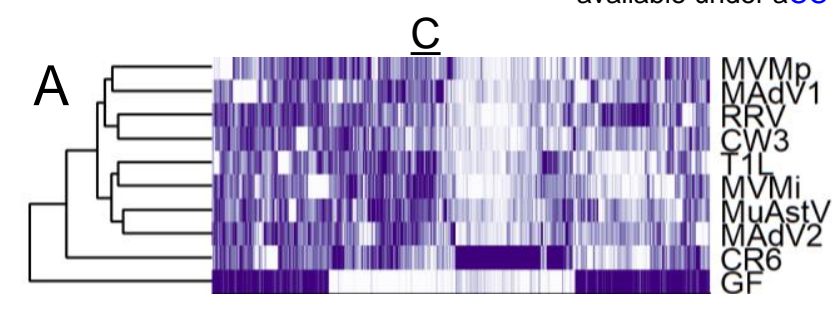

\begin{tabular}{l|c|c|}
\multicolumn{2}{l}{ C } & \multicolumn{2}{c}{ DE genes in } \\
& & $\begin{array}{c}\text { Small } \\
\text { Intestine }\end{array}$ \\
\hline All viruses & 497 & 355 \\
\hline CR6 & 181 & 62 \\
\hline CW3 & 35 & 41 \\
\hline MAdV1 & 55 & 40 \\
\hline MAdV2 & 46 & 35 \\
\hline MuAstV & 75 & 55 \\
\hline MVMi & 121 & 58 \\
\hline MVMp & 48 & 58 \\
\hline RRV & 22 & 41 \\
\hline T1L & 122 & 41 \\
\hline MDF & 146 & 92 \\
\hline
\end{tabular}
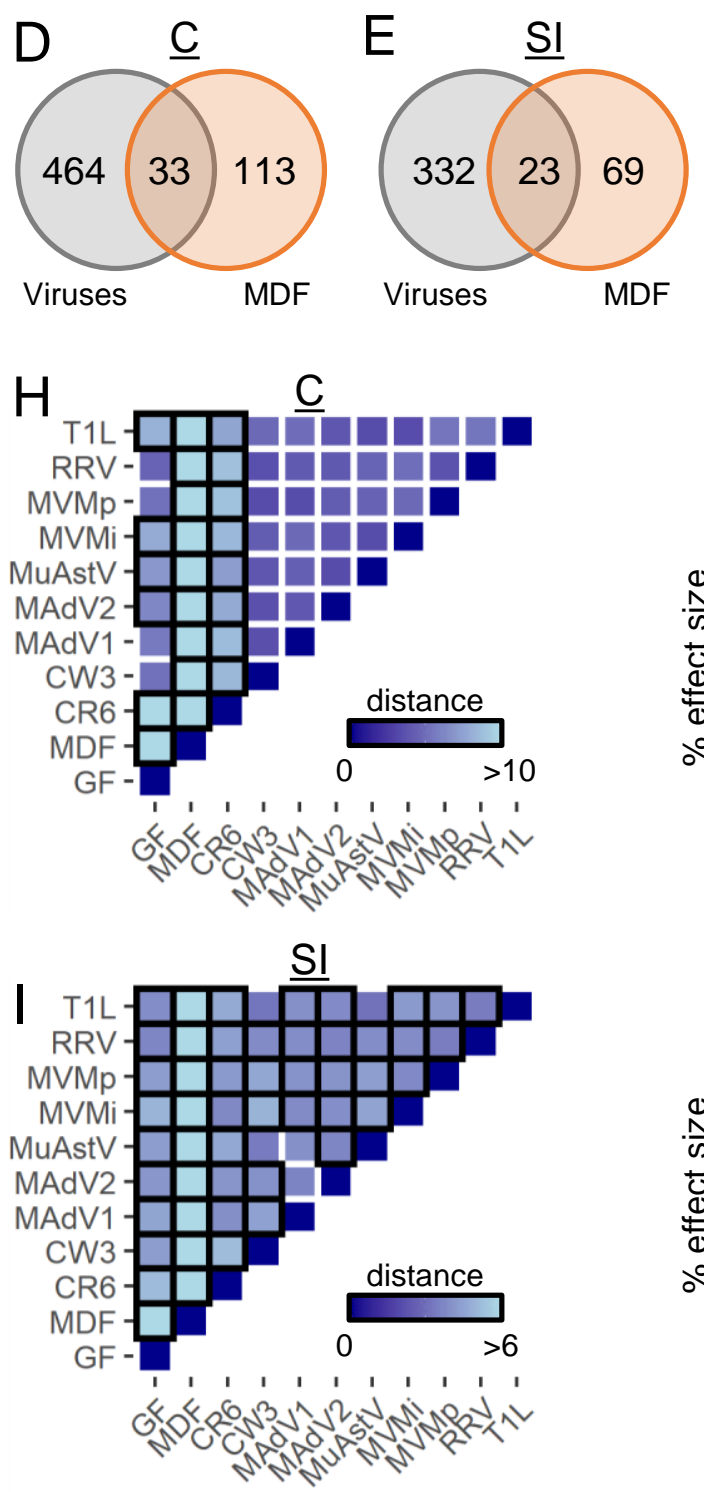

F

G
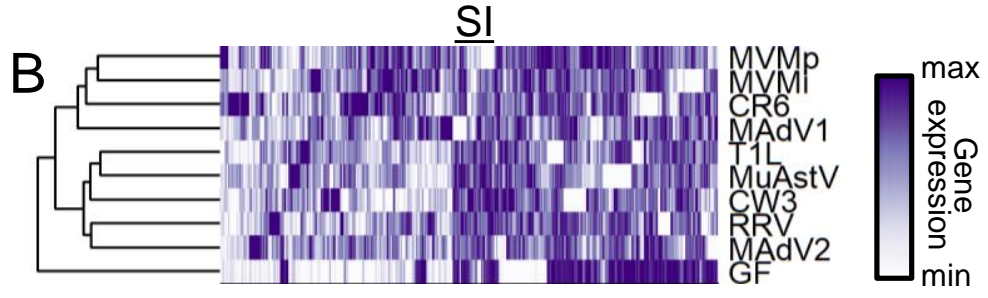

phagocytosis, recognition -: exogenous drug catabolic process regulation of ribonuclease activity ssing and presentation of exogenou - : arachidonic acid metabolic process complement activation, classical pathway -: cellular response to interferon-beta adhesion of symbiont to host $B$ cell receptor signaling pathway response to interferon-alpha -: phagocytosis, engulfment - : defense response to protozoan xenobiotic metabolic process - : regulation of interleukin-1 beta production positive regulation of $B$ cell activation negative regulation of viral genome replication antimicrobial humoral response -: defense response to bacterium cellular response to interferon-gamma $10^{-2} \bigcirc \bigcirc 10^{-10}$ o Viruses adjusted $p$-value $\circ \mathrm{MDF}$

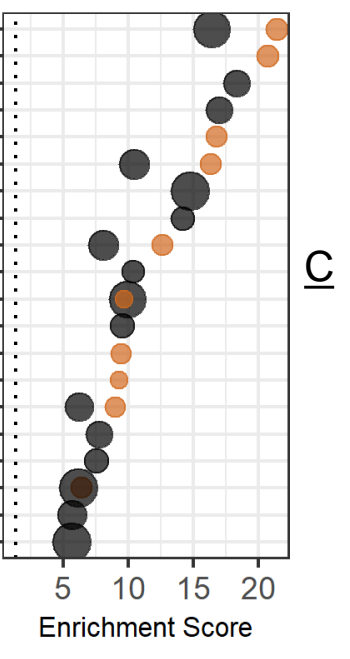

membrane disruption in other organism innate immune response in mucosa antibacterial humoral response phagocytosis, recognition antimicrobial humoral immune response mediated complement activation, classical pathway defense response to Gram-negative bacterium defense response to Gram-positive bacterium B cell receptor signaling pathway defense response to bacterium phagocytosis, engulfment positive regulation of $\mathrm{B}$ cell activation cellular response to lipopolysaccharide positive regulation of lymphocyte activationlymphocyte differentiation

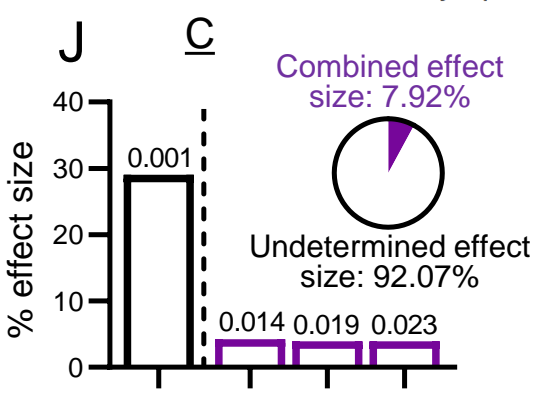

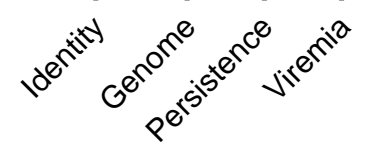

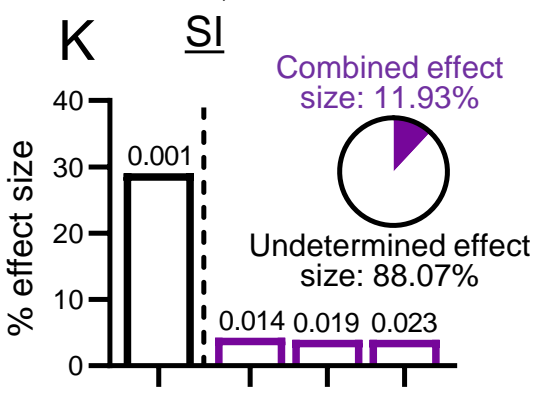

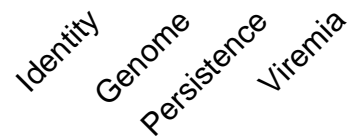

\section{L}

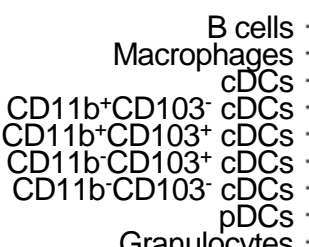

Monocyte waterfall $P$ 2 Monocyte waterfall $\mathrm{P} 3$ Monocyte waterfall $P 1$ CD $3^{+} \mathrm{y}^{+} \mathrm{T}$ cells $\mathrm{CD}^{+} \mathrm{CD}^{+} \mathrm{4}^{+} \mathrm{T}$ cells $\mathrm{FOXP3}^{+} \mathrm{CD}^{+} \mathrm{T}$ cells $\mathrm{FOXP} 3+\mathrm{RORY} \mathrm{CO}^{+} \mathrm{CD} 4+\mathrm{T}$ cells FOXP3 ${ }^{+}$RORyt CD4 ${ }^{+} \mathrm{T}$ cells GATA3+ CD $4+{ }^{+} T$ cells Naîve CD $4+{ }^{+} T$ cells Central memory $\mathrm{CD}^{+}{ }^{+} \mathrm{T}$ cells Effector memory CD4 ${ }^{+} \mathrm{T}$ cells

RORyt ${ }^{+}$CD $4+T$ cells $\mathrm{Tbet}^{+} \mathrm{CD}^{+} \mathrm{T}$ cells $\mathrm{CD} 3+\mathrm{CD} 8+T$ cells Naiive CD $8^{+} T$ cells Central memory CDD $8^{+}$
Effector memory cells
CD $8^{+}$ effect size Group 1 NKC 


\section{Figure 4. Intestinal Transcriptome of Virus-Infected Mice}

520 (A-B) Heatmaps showing DE genes (|average fold-change over GF $\mid \geq 2$ and unadjusted p-

521 value $\leq 0.01$ ) in the colon (A) and small intestine (B) of virus-infected mice compared with GF

522 mice. C: colon; SI: small intestine.

523 (C) Number of DE genes in the colonic and small intestinal transcriptome for each condition 524 compared with GF mice.

525 (D-E) Venn diagrams depicting the number and overlap of DE genes in all virus-infected and 526 MDF-associated mice in the colon (D) and small intestine (E).

527 (F-G) Top 15 most highly enriched biological process GO terms for the DE genes in the colon (F) 528 and small intestine $(\mathrm{G})$ of virus-infected and MDF-associated mice.

529 (H-I) Heatmaps showing the Euclidean distances between group centroids of DE genes in the colon

$530(\mathrm{H})$ and small intestine (I) comparing each condition. Boxes outlined in black indicate significant 531 differences (PERMANOVA<0.05).

$532(\mathrm{~J}-\mathrm{K})$ Effect size determined by db-RDA of virus characteristics as explanatory variables of the 533 DE gene variance in the colon $(\mathrm{J})$ and small intestine $(\mathrm{K})$. Pie charts represent the combined effect 534 size of genome, persistence, and viremia.

535 (L) Effect size determined by db-RDA of immune population frequencies from Figure 2 on DE 536 gene variance in the colon and small intestine. Boxes outlined in black indicate p-value $<0.05$. 
bioRxiv preprint doi: https://doi.org/10.1101/2020.10.20.347286; this version posted October 20,2020. The copyright holder for this preprint

(which was not certified by peer review) is the author/funder, who has granted bioRxiv a license to display the preprint in perpetuity. It is made available under aCC-BY-NC-ND 4.0 International license.
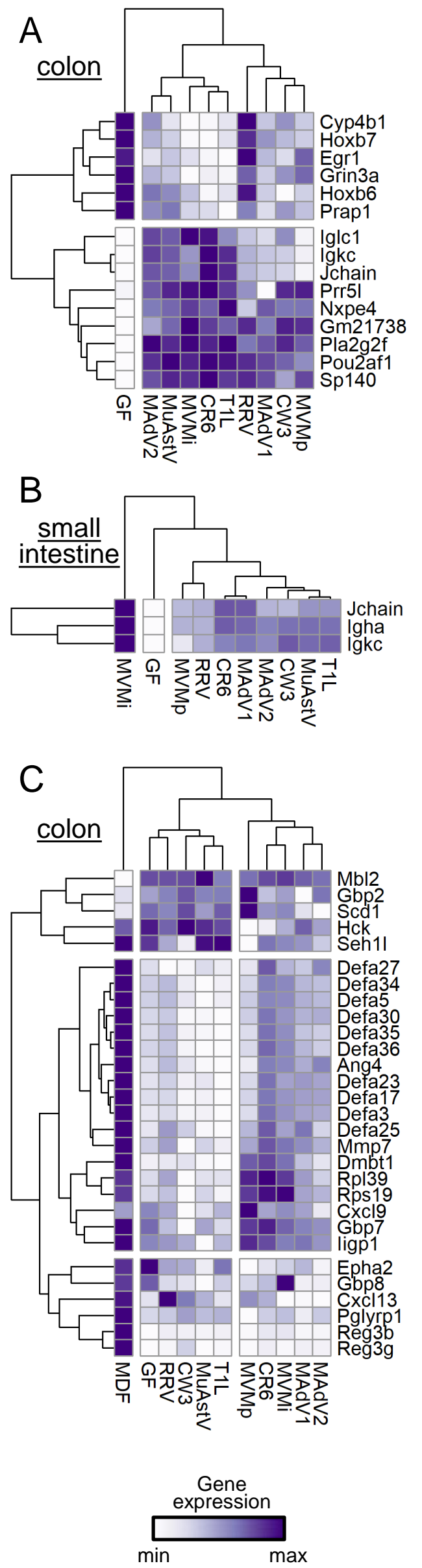
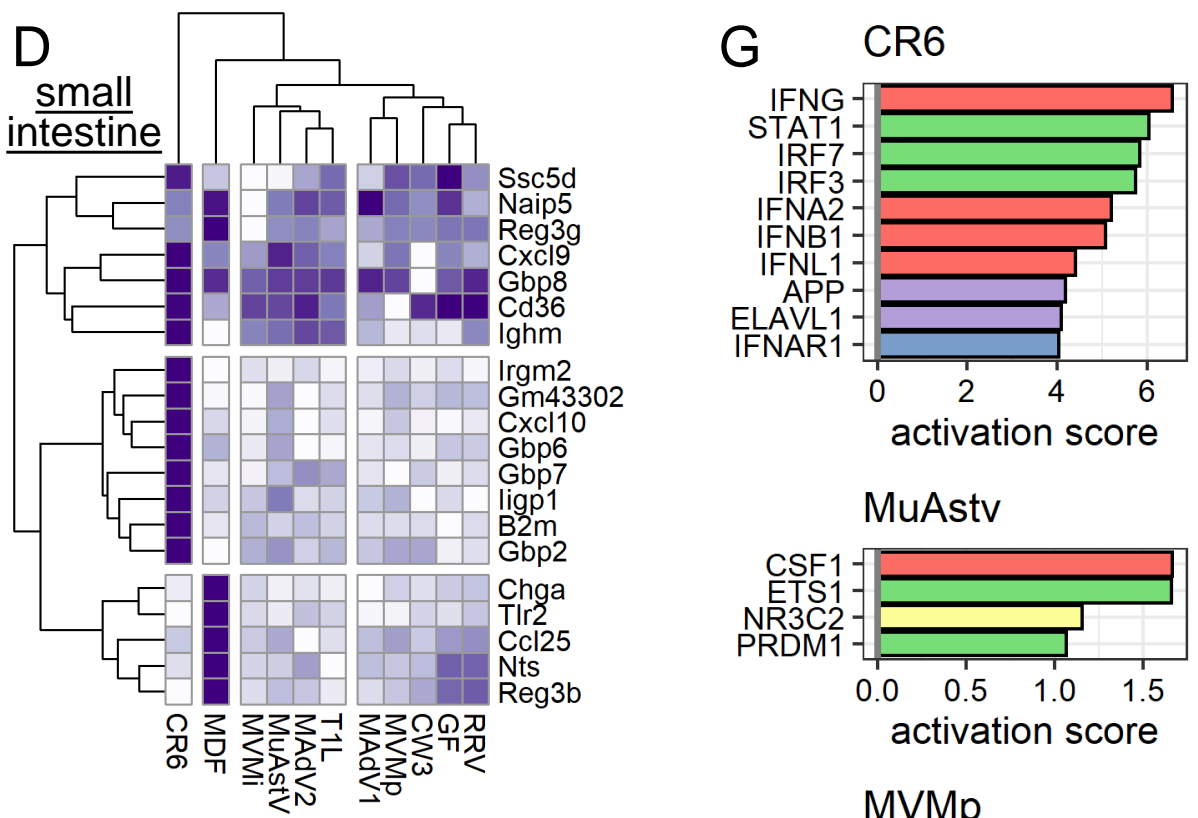

E
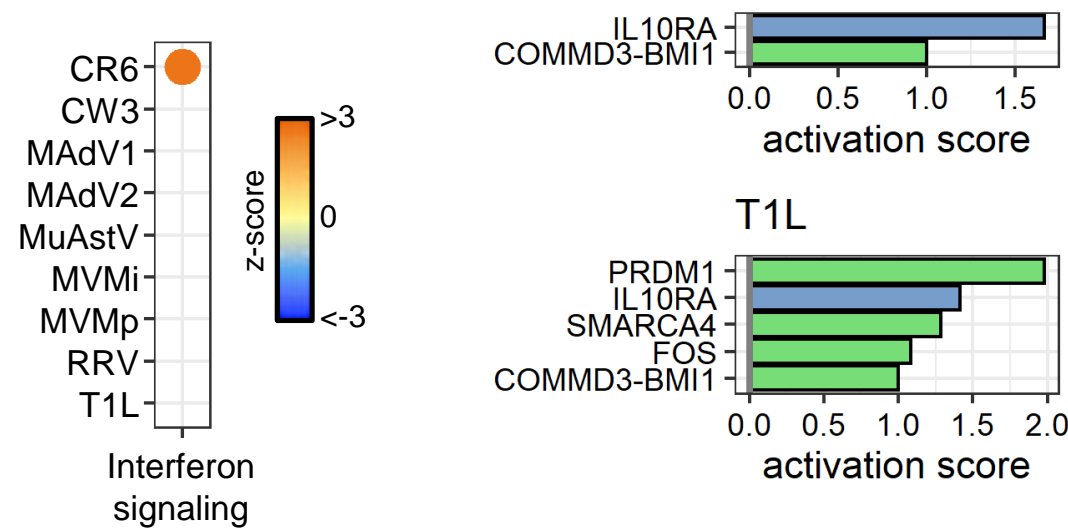

T1L

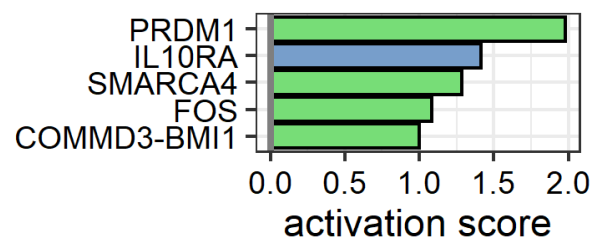

H MVMi



RRV

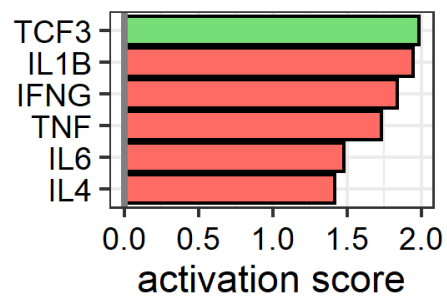

Cytokine

Other

Transcription regulator

Transmembrane receptor

Ligand-dependent nuclear receptor 


\section{Figure 5. Intestinal Gene Expression Common and Specific to Individual Viruses}

538 (A-B) Heatmaps displaying normalized expression values of DE genes (average fold-change over

$539 \mathrm{GF} \geq 2$ and unadjusted $\mathrm{p}$-value $\leq 0.01)$ modulated by at least five viruses in the colon (A) and small

540 intestine (B).

541 (C-D) Heatmaps displaying normalized expression values of DE genes (average fold-change over

$542 \mathrm{GF} \geq 1.5$ and unadjusted $\mathrm{p}$-value $\leq 0.01$ ) annotated in GO:0050829, GO:0050830, and GO:0061844

543 in the colon (C) and small intestine (D).

544 (E-F) Ingenuity pathway analysis (IPA) of the colonic transcriptome of virus-infected mice for

545 enrichment of DE genes involved in IFN signaling (E) or key molecules in the IFN pathway (F).

546 (G-H) Colonic $(\mathrm{G})$ and small intestinal $(\mathrm{H})$ DE genes were analyzed by IPA for upstream

547 regulators. Top 10 upstream regulators for each virus with an activation score $>1$ are depicted. 
bioRxiv preprint doi: https://doi.org/10.1101/2020.10.20.347286; this version posted October 20, 2020. The copyright holder for this preprint (which was not certified by peer review) is the author/funder, who has granted bioRxiv a license to display the preprint in perpetuity. It is made available under aCC-BY-NC-ND 4.0 International license.

A

Colon gene sets (upregulated)

Acinetobacter Iwoffii F78 Bacteroides finegoldii DSM17565 Bacteroides ovatus ATCC8483 Bacteroides uniformis ATCC8492

Bacteroides vulgatus ATCC8482 Campylobacter jejuni AS-84-79Clostridium histolyticum AO25 Enterococcus faecalis TX0104 Parabacteroides distasonis ATCC8503-

Porphyromonas uenonis UPII60-3Ruminococcus gnavus ATCC29149Specific Pathogen Free (SPF) Veillonella 6_1_27

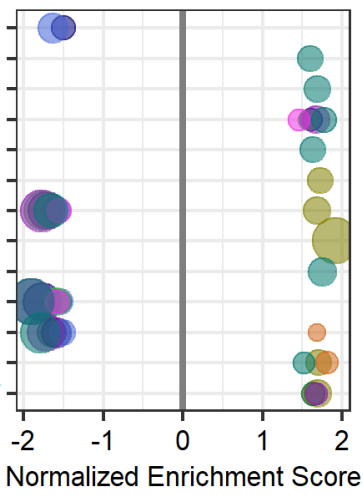

C Small Intestine gene sets (upregulated) Acinetobacter Iwoffii F78
Bifidobacterium adolescentis $L 2-32$ Clostridium ramosum $A O 31$ Fusobacterium nucleatum F0419Lachnospiraceae sp_2_1_58FAA Parabacteroides distasonis A $\bar{T} \bar{C} C 8503$ Parabacteroides merdae CLO3T12C32 Porphyromonas uenonis UPII60-3 Propionibacterium granulosum AO42 Specific Pathogen Free (SPF) Veillonella 6_1_27

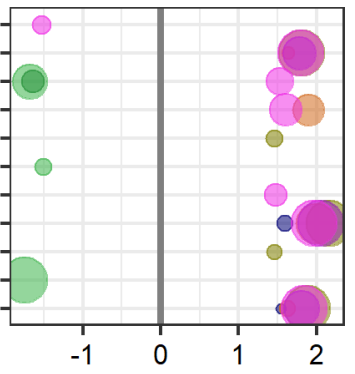

Normalized Enrichment Score

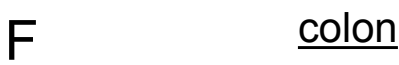

$E$ E. faecalis
gene set: up

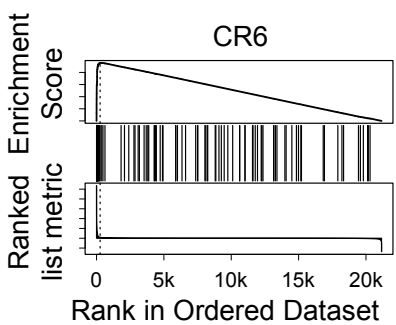

Clusters:

- 1

$-2$

- 3

$-4$

- 5
B

Colon gene sets (downregulated)

Bacteroides thetaiotaomicron ATCC29148Fusobacterium mortiferum AO16Porphyromonas uenonis UPll60-3Ruminococcus gnavus ATCC29149-

$\begin{array}{llll}0.0 & 0.5 & 1.0 & 1.5\end{array}$

Normalized Enrichment Score

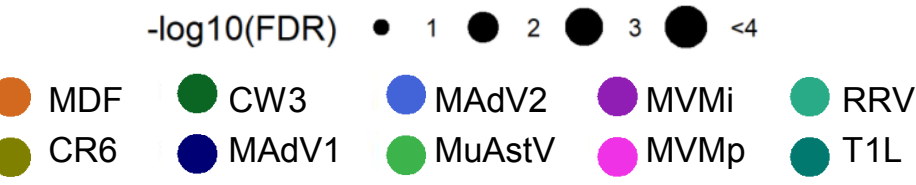

D Small Intestine gene sets (downregulated)

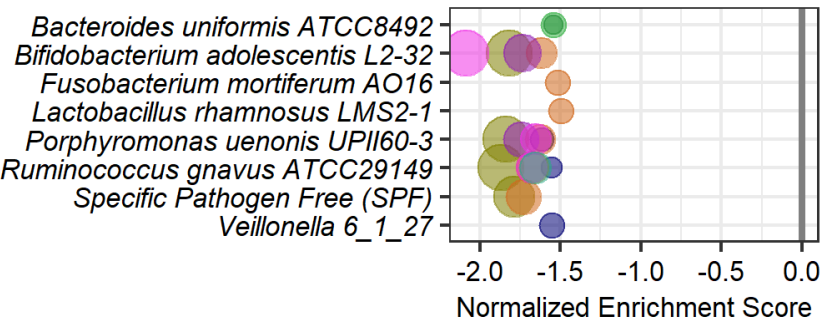

Bacteroides uniformis ATCC8492 -

Fusobacterium mortiferum A016

Lactobacillus rhamnosus LMS2-1

Porphyromonas uenonis UPII60-3

Veillonella 6127

Normalized Enrichment Score
T1L 


\section{Figure 6. Intestinal Transcriptomes of Virus-Infected Mice Are Enriched for Bacterial}

\section{Microbiome Gene Signatures}

550 (A-D) Colonic (A-B) and small intestinal (C-D) transcriptomes from virus-infected mice compared

551 with gene expression signatures of bacterially colonized mice by GSEA. Gene sets upregulated

552 following colonization by bacteria are depicted in A and C; downregulated gene sets are depicted 553 in B and D.

554 (E) GSEA plot showing enrichment of the E. faecalis upregulated gene set in the colonic 555 transcriptome of mice infected with MNV CR6.

556 (F-G) Hierarchical clustering of the immune population frequencies described in Table S4. Purple:

557 viruses; dark purple: MDF and GF from this study; orange: bacteria; pink: conventional SPF and 558 GF from Geva-Zatorsky et al. 


\begin{tabular}{|c|c|c|c|c|c|c|c|c|}
\hline $\begin{array}{c}\text { Viral } \\
\text { family } \\
\text { (-viridae) }\end{array}$ & $\begin{array}{c}\text { Viral } \\
\text { genus } \\
\text { (-virus) }\end{array}$ & $\begin{array}{c}\text { Baltimore } \\
\text { classif. } \\
\text { (genome) }\end{array}$ & Virus & Strain & Abbr. & Persistent & Viremia & $\begin{array}{c}\text { Cause } \\
\text { pathology }\end{array}$ \\
\hline \multirow{2}{*}{ Adeno- } & \multirow{2}{*}{ Mastadeno- } & \multirow{2}{*}{$\begin{array}{c}\mathrm{I} \\
(\mathrm{dsDNA})\end{array}$} & \multirow{2}{*}{$\begin{array}{c}\text { Murine } \\
\text { Adenovirus }\end{array}$} & MAdV1 & MAdV1 & Yes & Yes & No \\
\hline & & & & MAdV2 & MAdV2 & No & No & No \\
\hline Astro- & Mamastro- & $\begin{array}{c}\text { IV } \\
(\text { ssRNA+) }\end{array}$ & $\begin{array}{c}\text { Murine } \\
\text { Astrovirus }\end{array}$ & NYU1 & MuAstV & Yes & Yes & No \\
\hline \multirow{2}{*}{ Calici- } & \multirow{2}{*}{ Noro- } & \multirow{2}{*}{$\begin{array}{c}\mathrm{IV} \\
(\mathrm{ssRNA}+)\end{array}$} & \multirow{2}{*}{$\begin{array}{l}\text { Murine } \\
\text { Norovirus }\end{array}$} & CR6 & CR6 & Yes & No & No \\
\hline & & & & CW3 & CW3 & No & No & No \\
\hline Picorna- & Entero- & $\begin{array}{c}\text { IV } \\
(\text { ssRNA+) }\end{array}$ & $\begin{array}{c}\text { Coxsackie } \\
\text { virus B3 }\end{array}$ & $\mathrm{H} 3$ & CVB3 & n.d. & n.d. & Yes, lethal \\
\hline \multirow[t]{2}{*}{ Parvo- } & \multirow[t]{2}{*}{ Protoparvo- } & \multirow{2}{*}{$\begin{array}{c}\text { II } \\
\text { (ssDNA) }\end{array}$} & \multirow[t]{2}{*}{$\begin{array}{l}\text { Minute virus of } \\
\text { mice }\end{array}$} & $\begin{array}{l}\text { Immunotr } \\
\text { opic }\end{array}$ & MVMi & Yes & Yes & No \\
\hline & & & & Prototype & MVMp & Yes & No & No \\
\hline \multirow{2}{*}{ Reo- } & Orthoreo- & \multirow{2}{*}{$\begin{array}{c}\text { III } \\
\text { (dsRNA) }\end{array}$} & $\begin{array}{c}\text { Mammalian } \\
\text { orthoreovirus } 1\end{array}$ & $\begin{array}{l}\text { Type } 1 \\
\text { Lang }\end{array}$ & T1L & No & No & No \\
\hline & Rota- & & $\begin{array}{c}\text { Simian rhesus } \\
\text { rotavirus }\end{array}$ & RRV & RRV & No & No & No \\
\hline
\end{tabular}

559 Table 1: Summary of characteristics of viruses. Taxonomic classification at the family and

560 genus level, Baltimore classification, virus strain names with their abbreviations (Abbr.), and

561 summary of results following inoculation of germ-free (GF) mice from Fig. 1 and S1 for each virus

562 used in this study. Viruses were categorized as persistent if viral nucleic acid was detected at 30

563 days post inoculation (dpi) in blood or stool following oral inoculation. Viremia is defined as the

564 presence of viral nucleic acid in the blood in at least one time point. The ability to cause pathology

565 is based on the appearance of histological or macroscopic signs of disease, such as lethality or

566 diarrhea. n.d.: not determined. 


\section{Material and methods}

$568 \underline{\text { Mice }}$

569 GF C57BL/6J were bred in flexible-film isolators at the New York University Grossman School 570 of Medicine Gnotobiotics Animal Facility. Absence of fecal bacteria was confirmed monthly by 571 evaluating the presence of 16S DNA in stool samples by qPCR as previously described (Kernbauer 572 et al., 2014). For experiments, GF mice were housed in Bioexclusion cages (Tecniplast) with 573 access to sterile food and water. Conventional C57BL/6J and Rag ${ }^{-1}$ mice were purchased from 574 The Jackson Laboratory (Bar Harbor, ME, USA). Experiments depicted in Fig. 1 were performed using GF mice from both sexes and conventional male mice. Experiments depicted in Fig. 2-5 were performed using GF female mice. Each independent experiment comprised 8-12 mice and untreated GF mice were included in each round. Each microbial association was evaluated in 5-7 mice from at least 2 independent experiments. Littermates were randomly assigned to the experimental groups and mice were never single-housed. All animal studies were performed according to protocols approved by the NYU Grossman School of Medicine Institutional Animal Care and Use Committee.

Virus production

583 MNV strains CR6 and CW3 stocks were prepared by transfecting 293T cells (ATCC) with 584 plasmids containing the viral genome (described in (Sutherland et al., 2018)) using XtremeGENETM HP DNA Transfection Reagent (Roche, Indianapolis, IN, USA). Supernatants were applied to RAW264.7 cells (ATCC) for two rounds of amplification, followed by 587 ultracentrifugation of the supernatant and resuspension in endotoxin-free PBS (Corning, Corning,

588 NY, USA) to generate viral stocks. Concentration of stock was determined by plaque assay 589 (described below) on RAW264.7 cells overlaid with DMEM (Corning) + 1\% methylcellulose 590 (Sigma-Aldrich, St. Louis, MO, USA) and evaluated 3 days later using crystal violet.

591 CVB3 strain H3 stock was prepared by transfecting HeLa cells (ATCC) with plasmids containing 592 the viral genome and the T7 polymerase, a gift from Dr. Pfeiffer J (UT Southwestern, Dallas, TX, 593 USA), using Lipofectamine 3000 (Thermo Fisher Scientific, Rochester, NY, USA). Cell lysate 594 was applied to HeLa cells for two rounds of amplification. Then, the cell lysate was resuspended 595 in PBS $+1 \mathrm{mM} \mathrm{MgCl} 2$ and $1 \mathrm{mM} \mathrm{CaCl}_{2}$, and freeze/thawed, and the supernatant was collected 596 and used as viral stock. Stock titer was determined by plaque assay (described below) on HeLa 
cells overlaid with MEM (Lonza, Walkersville, MD, USA) + 0.5\% agarose (Thermo Fisher

598 Scientific, Waltham, MA, USA) and evaluated 3 days later using crystal violet.

599 MAdV1, MAdV2, and CMT93 cells were a gift from Dr. Smith JG (University of Washington,

600 Seattle, WA, USA). Viruses were expanded on CMT93 cells and supernatants were collected and

601 used as viral stocks. Concentration of stocks were determined by focus forming assay (described

602 below) on CMT93 cells.

603 MuAstV-NYU1 stock was generated from the stool of Rag1 $1^{-/-}$mice bred at NYU Grossman School

604 of Medicine. Briefly, stools from 6-10 weeks old mice were harvested and homogenized in PBS.

605 Fecal slurry was pelleted, and supernatant was filtered twice using $0.22 \mu \mathrm{m}$ Millex-GP syringe-

606 driven filter unit (MilliporeSigma, Burligton, MA, USA). Viral titer was determined by qPCR after

607 RNA extraction and retrotranscription.

608 MVMi and MVMp were a gift from Dr. Pintel D (University of Missouri, Columbia, MO, USA), 609 and NB324K cells were a gift from Dr. Tattersall P (Yale University, New Haven, CT, USA). 610 Viruses were expanded on NB324K cells and either cell lysate (MVMp) or supernatant (MVMi) 611 were used as viral stocks. Concentration of stocks were determined by focus forming assay 612 (described below) on NB324K cells.

613 RRV and MA-104 cells were a gift from Dr. Greenberg HB (Stanford University, Stanford, CA, 614 USA). Virus was expanded on MA-104 cells and supernatant was collected and used as viral stock.

615 Concentration of stock was determined by plaque assay (described below) on MA-104 cells 616 overlaid with M199 (Sigma-Aldrich) + 0.5\% agarose and evaluated 5 days later using neutral red.

617 Reovirus T1L was prepared as described (Sutherland et al., 2018). T1L was quantified by plaque 618 assay using L929 cells overlaid with DMEM containing 1\% agar and evaluated 6 days later 619 following neutral red staining (Sutherland et al., 2018).

$620 \quad$ Viral inoculation

621 Viruses were administered to mice by oral gavage at about 5 weeks of age. Doses administered 622 were $3 \times 10^{6} \mathrm{PFU} / \mathrm{mouse}$ for MNV CR6 and CW3; $1 \times 10^{7} \mathrm{PFU} / \mathrm{mouse}$ for CVB3; $1 \times 10^{6} \mathrm{FFU} / \mathrm{mouse}$ 623 for MAdV1; $5 \times 10^{4} \mathrm{FFU} /$ mouse for MAdV2; $1 \times 10^{10}$ genome copies/mouse for MuAstV; $2 \times 10^{5}$

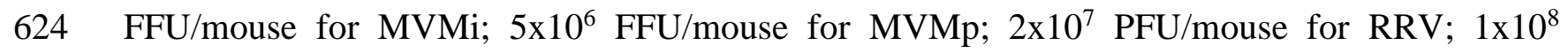
625 PFU/mouse for T1L. For experiments depicted in Fig. 1 stool and blood were collected before 626 viral inoculation and at 2, 5, 10, 30 and 60 days after inoculation. For experiments depicted in Fig. 
627 2-5, stool was collected before viral inoculation and at 5 and 28 days after inoculation, whereas

628 blood was collected 28 days after inoculation.

629 Sample processing and nucleic acid extraction

630 Stool samples were homogenized in PBS for nucleic acid extraction by mechanical disruption with 631 zircon beads (BioSpec Products, Bartlesville, OK, USA) using a FastPrep-24 machine (MP

632 Biomedicals, Solon, OH, USA). Lysate slurry was spun down at $2000 \mathrm{~g}, 5 \mathrm{~min}, 4^{\circ} \mathrm{C}$ and the 633 supernatant was spun down again at $8000 \mathrm{~g}, 5 \mathrm{~min}, 4^{\circ} \mathrm{C}$ to completely remove debris. Colon and 634 small intestine segments were mechanically disrupted in PBS with metal beads (Qiagen) using a 635 FastPrep-24 machine. Subsequently, lysate slurry was spun down at $8000 \mathrm{~g}, 5 \mathrm{~min}, 4^{\circ} \mathrm{C}$ to remove 636 debris and a portion of the supernatant was used for RNA extraction. DNA was purified using 637 DNeasy Blood \& Tissue Kits (Qiagen) according to the manufacturer's protocol. RNA was 638 purified using RNeasy extraction kits (Qiagen) with a DNase (Qiagen) incubation step according 639 to the manufacturer's protocol. $200 \mu \mathrm{L}$ of stool PBS homogenate and $50 \mu \mathrm{L}$ of blood were used 640 for nucleic acid extraction. cDNA was synthesized using ProtoScript First Strand cDNA Synthesis 641 Kit (NEB) using random primers according to the manufacturer's protocol. All cDNA products 642 were stored at $-20^{\circ} \mathrm{C}$.

\section{$643 \quad$ Viral quantification}

644 For plaque assays, samples were serially diluted in PBS or DMEM and $500 \mu \mathrm{L}$ were used to 645 overlay almost confluent cells in 6 well plates (Corning). Cells were incubated at $37^{\circ} \mathrm{C}$ and gently 646 shaken every 15 minutes. After $1 \mathrm{~h}$, inoculum was removed, and cells were overlaid with the semi647 solid media described above. After the number of days indicated above, cells were either fixed by 648 adding PBS $+4 \%$ PFA (Sigma-Aldrich) for $1 \mathrm{~h}$ and then stained with crystal violet or incubated 649 ON with PBS $+0.05 \%$ Neutral Red (Sigma, St Louis, MO, USA) and fixed with PBS + 4\% PFA 650 for $1 \mathrm{~h}$.

651 For focus forming assays, samples were serially diluted in PBS or DMEM and $50 \mu \mathrm{L}$ were used 652 to overlay almost confluent cells in a 96 multi-well clear-bottom black plate (Corning). Cells were 653 incubated at $37^{\circ} \mathrm{C}$ and gently shaken every 15 minutes. After $1 \mathrm{~h}$, inoculum was removed and cells 654 were overlaid with DMEM + 10\% fetal bovine serum (GE Healthcare Life Science, Piscataway, 655 NJ, USA). After 1 day, cells were fixed with HyClone Water (GE Healthcare Life Science) + 2\% 656 PFA for $20 \mathrm{~min}$ on ice, and then permeabilized with a quench/perm buffer (20 mM glycine, $0.25 \%$ 657 TX-100 in PBS) for 20 min on ice. Cells were then stained with a primary antibody for $1 \mathrm{~h}$ on ice. 
Anti-adenovirus antibody clone 8C4 (Fitzgerald Industries) was used to detect MAdV1 and MAdV2), and a non-commercial $\alpha$-MVM NS protein antibody previously described (Yeung et al., 1991, a gift from Dr. Tattersall P) was used to detect MVM. Then, we stained for 15 min on ice with a secondary $\alpha$-mouse IgG AF488 (Thermo Fisher Scientific) and DAPI (Sigma-Aldrich).

662 Plates were imaged using an EVOS Cell Imaging System (Thermo Fisher Scientific) and focus

663 forming units were manually enumerated using ImageJ (NIH).

664 Quantification of viral nucleic acid was performed on DNA and cDNA samples using LightCycler 665480 SYBR Green I Master or LightCycler 480 Probes Master (Roche), and absolute amount was 666 calculated by comparison with in-house linearized plasmid standards. Primer and probe sequences 667 are reported in Table S5.

\section{$668 \quad$ Plaque reduction neutralization test}

669 Serum was recovered from blood collected from the submandibular vein at 20-30 days after viral 670 inoculation. Serum inactivated for $30 \mathrm{~min}$ at $56^{\circ} \mathrm{C}$ was diluted in PBS and the same amount of 671 virus was added to all conditions before $1 \mathrm{~h}$ incubation at $37^{\circ} \mathrm{C}$. Then, this mix was used as 672 inoculum for plaque assay and focus forming assay, which were performed as previously 673 described.

\section{Organ processing}

675 Colon, small intestine, mesenteric lymph nodes, lungs, and spleen were harvested from untreated 676 GF mice or GF mice 28 days after inoculation with viruses and bacteria.

677 A segment of the distal colon (4 $\mathrm{mm}$ long and $3 \mathrm{~cm}$ away from the rectum) and three segments of 678 the midsection of the duodenum, jejunum, and ileum (each $2 \mathrm{~mm}$ long) were collected and kept at $679-80^{\circ} \mathrm{C}$ until RNA isolation. Additionally, $3 \mathrm{~mm}$ from the distal colon and from the ileum were 680 collected and fixed in formalin (Thermo Fisher Scientific) for histological analysis.

681 For single cells suspension, small intestinal and colonic tissues were flushed with PBS, fat and 682 Peyer's patches were removed, and the tissues were incubated first with $20 \mathrm{~mL}$ of HBSS (Gibco) 683 with $2 \%$ HEPES (Corning), $1 \%$ sodium pyruvate (Corning), 5mM EDTA, and $1 \mathrm{mM}$ dithiothreitol 684 (Sigma-Aldrich) for $15 \mathrm{~min}$ at $37^{\circ} \mathrm{C}$, and then with new $20 \mathrm{~mL}$ of HBSS with $2 \%$ HEPES, $1 \%$ 685 sodium pyruvate, $5 \mathrm{mM}$ EDTA for $10 \mathrm{~min}$ at $37^{\circ} \mathrm{C}$. Tissue bits were washed in $\mathrm{HBSS}+5 \% \mathrm{FCS}$, 686 minced, and then enzymatically digested with collagenase D (0.5 mg/mL, Roche) and DNAse I $687\left(0.01 \mathrm{mg} / \mathrm{mL}\right.$, Sigma-Aldrich) for $30-45 \mathrm{~min}$ at $37^{\circ} \mathrm{C}$ with constant stirring. Digested solutions 
were passed through $70 \mu \mathrm{m}$ cell strainers (BD) and cells were subjected to gradient centrifugation using 40\% Percoll (Sigma-Aldrich).

IELs were recovered from the liquid phase of the first small intestine incubation, washed with PBS, and subjected to gradient centrifugation using $40 \%$ Percoll.

692 mLNs were collected and passed through $100 \mu \mathrm{m}$ cell strainers and resuspended in PBS.

693 Lungs and spleens were grossly minced and enzymatically digested with collagenase D (0.5 $694 \mathrm{mg} / \mathrm{mL})$ and DNAse I $(0.01 \mathrm{mg} / \mathrm{mL})$ for $20-30 \mathrm{~min}$ at $37^{\circ} \mathrm{C}$. Digested solutions were passed 695 through $100 \mu \mathrm{m}$ cell strainers, resuspended in ACK buffer to lyse the red blood cells, and resuspended in PBS.

697 For the analysis of the cytokine production, cells were plated in RPMI with 10\% FBS and treated 698 with phorbol 12-myristate 13 -acetate $(50 \mathrm{ng} / \mathrm{mL}$, MilliporeSigma) and ionomycin $(1 \mu \mathrm{g} / \mathrm{mL}$, MilliporeSigma) in the presence of GolgiStop (BD) and GolgiPlug (BD) for $4 \mathrm{~h}$ at $37^{\circ} \mathrm{C}$.

$700 \quad$ Flow Cytometry

701 Cells were pre-incubated with CD16/CD32 Fc block (BD PharMingen). Surface and intracellular 702 cytokine staining was performed per manufacturer's instructions in PBS $+2 \%$ FBS for 20 min on 703 ice. Three staining panels were utilized. The first panel included antibodies against BST2, NK1.1, 704 THY1.2, F4/80, CD103, LY6C, CD11b, MHC-II, CD45, CD11c, CD19, CD64, and B220. To 705 stain the spleen samples, we substituted CD103 with CD8a for a better evaluation of the dendritic 706 cell subsets. The second panel included antibodies against GATA3, CD11b, CD11c, GR1, CD19, 707 TER119, Tbet, TCR $\gamma \delta$, FOXP3, CD8, CD4, ROR $\gamma \mathrm{t}, \mathrm{CD} 62 \mathrm{~L}, \mathrm{CD} 127, \mathrm{NK} 1.1, \mathrm{CD} 44, \mathrm{CD} 3 \varepsilon, \mathrm{CD} 45$. 708 The third panel included antibodies against IFN- $\gamma$, CD11b,CD11c, GR1, CD19, TER119, Nk1.1, 709 Il-22, TCR $\gamma \delta$, GRANZYME B, IL-17a, CD8, CD4, IL-10, CD127, IL-4, CD3E, CD45. Samples 710 were fixed with either Fixation Buffer (Biolegend, San Diego, CA, USA) or eBioscience 711 Foxp3/Transcription Factor Staining Buffer Set (Thermo Fisher Scientific). For intracellular 712 staining of transcription factor, cells were permeabilized with the eBioscience 713 Foxp3/Transcription Factor Staining Buffer Set at room temperature for $30 \mathrm{~min}$ in the presence of 714 antibodies. For intracellular staining of cytokines, cells were permeabilized with Intracellular 715 Staining Permeabilization Wash Buffer (Biolegend) at room temperature for $30 \mathrm{~min}$ in the 716 presence of antibodies. Zombie UV Fixable Viability Kit (Biolegend) was used to exclude dead 717 cells. Samples were acquired on a BD LSR II (BD Biosciences) and analyzed using FlowJo 718 software (Treestar, Inc., Ashland, OR, USA). 


\section{RNA deep sequencing}

720 CEL-seq2 was performed on 67 colonic and 60 small intestinal RNA samples. Sequencing was

721 performed on Illumina NovaSeq 6000 (Illumina). All samples from the same organs were

722 sequenced together, thus no correction for batch effect was necessary.

723 Microscopy on intestinal tissue

724 Small intestinal and colonic tissues were cut open along the length, pinned on black wax, and fixed

725 in 10\% formalin. Tissues were embedded in 3\% low melting point agar (Promega, Madison, WI,

726 USA). Formalin embedding, cutting, and hematoxylin and eosin staining was performed by the

727 NYU Histopathology core. Sections were imaged either on a Leica SCN400 F microscope (Leica

728 Biosystems, Buffalo Grove, IL, USA).

$729 \underline{\text { Bacteria }}$

730 The Minimal Defined Flora consisted of the 15 bacteria described in Brugiroux et al., 2016.

731 Akkermansia muciniphila YL44 was a gift from Dr. McCoy K (University of Calgary, Canada)

732 and it was grown in $0.1 \%$ mucin (Sigma-Aldrich), anaerobic, $37^{\circ} \mathrm{C}$. Bacteroides caecimuris $\mathrm{I} 48$

733 was from DSMZ and it was grown in BHI (Anaerobe Systems,), anaerobic, $37^{\circ} \mathrm{C}$. Muribaculum

734 intestinale YL27 (DSMZ) was grown in chopped meat media (Anaerobe Systems), anaerobic,

$73537^{\circ} \mathrm{C}$. Turicimonas muris was a gift from Dr. McCoy K and it was grown in $\mathrm{BHI}$, anaerobic, $37^{\circ} \mathrm{C}$.

736 Escherichia coli Mt1B1 (DSMZ) was grown in LB (Sigma-Aldrich), aerobic, $37^{\circ} \mathrm{C}$.

737 Bifidobacterium longum subsp. animalis YL2 (DSMZ) was grown in BHI, anaerobic, $37^{\circ} \mathrm{C}$.

738 Staphylococcus xylosus 33ERD13C (DSMZ) was grown in TSB-yeast (Sigma Aldrich), aerobic,

$73937^{\circ} \mathrm{C}$. Streptococcus danieliae ERD01G (DSMZ) was grown in TSB-yeast, microaerophilic, $37^{\circ} \mathrm{C}$.

740 Enterococcus faecalis KB1 (DMSZ) was grown in TSB-yeast, aerobic, $30^{\circ} \mathrm{C}$. Acutalibacter muris

$741 \mathrm{~KB} 18$ (DSMZ) was grown in BHI, anaerobic, $37^{\circ} \mathrm{C}$. Clostridium clostridioforme YL32 (DSMZ)

742 was grown in PYG (Anaerobe Systems), anaerobic, $37^{\circ} \mathrm{C}$. Flavinofractor plautii YL31 (DSMZ)

743 was grown in PYG, anaerobic, $37^{\circ} \mathrm{C}$. Blautia coccoides YL58 (DSMZ) was grown in chopped

744 meat media, anaerobic, $37^{\circ} \mathrm{C}$. Lactobacillus reuteri I49 (DMSZ) was grown in MRS,

745 microaerophilic, $37^{\circ} \mathrm{C}$. Clostridium innocuum I46 (DSMZ) was grown in chopped meat media or

$746 \quad \mathrm{PYG}$, anaerobic, $37^{\circ} \mathrm{C}$.

747 Yersinia Pseudotubercolosis was a gift from Dr. Darwin A (NYU), and it was grown overnight in

748 Luria-Bertani broth with shaking at $28^{\circ} \mathrm{C}$. In the morning, the bacterial were subcultured in fresh

749 Luria-Bertani broth with shaking at $28^{\circ} \mathrm{C}$ until OD $0.7-0.9$. Bacterial density was confirmed by 
dilution plating. 9-week-old female GF mice were inoculated by oral gavage with $2 \times 10^{4} \mathrm{CFU}$ resuspended in $200 \mu \mathrm{l}$ PBS. Severity of disease was quantified through a scoring system in which

752 individual mice received a score of 1 in case of the presence of visible blood in the stool, and 753 between 0 and 2 of the following: hunched posture and diarrhea.

\section{Quantification and statistical analysis}

755 Immunophenotypes

756 Flow cytometry fold change values were calculated by dividing the frequency of a given cell type 757 by the average frequency obtained from the GF mice in the same experimental round. Statistical 758 differences between each colonization condition and the GF mice were calculated by one-way 759 ANOVA followed by Dunn's post-hoc analysis using the R package "stats". To control for 760 multiple testing, a false discovery rate was calculated by the Benjamini-Hochberg procedure using 761 the R package "stats" for each cell type analyzed.

762 Selection of differentially expressed genes

763 RNA-Seq results were processed using the R package "DESeq2" to obtain variance stabilized 764 count reads, fold changes relative to GF condition, and statistical p-value. Analysis of the whole 765 tissue transcriptome focused on differentially expressed genes, defined as the genes with an 766 absolute fold change relative to GF $>2$ and an unadjusted p-value $<0.01$.

\section{Computational analysis}

768 Hierarchical clustering of the population and cytokine frequencies were performed on the 769 Euclidean distances using the R package "stats". Distance-based redundancy analysis (db-RDA) 770 was used to determine the contribution of different factors to the variance observed within the 771 immunophenotypes samples or differentially expressed genes using the R package "vegan". 772 Euclidean distance between colonization conditions according to differentially expressed genes 773 was calculated using the R package "stats", and permutational multivariate analysis of variance on 774 these distances was calculated using the R package "vegan”. Heatmaps were generated using either 775 the package "ggplot2" or "pheatmap". Gene ontology analysis was performed using the package 776 “clusterProfiler". GSEA was performed using the package "WebGestaltR". Canonical pathway 777 and upstream regulators analysis were performed by uploading the differentially expressed genes 778 to Ingenuity Pathway Analysis software (Qiagen). 


\section{$779 \quad$ GSEA gene signatures}

780 GSEA gene signatures were generated in a manner similar to Godec et al., 2016 by selecting the

781 top upregulated or downregulated genes, up to 200, with an FDR $<0.02$ or an unadjusted p-

782 value $<0.001$. Gene signatures consisting of less than 10 genes were discarded. IL-22 and bacterial

783 signatures were based on the transcriptional data described in Gronke et al., 2019 and Geva-

784 Zatorsky et al., 2017, respectively.

$785 \quad$ Statistical analysis

786 Statistical differences were determined as described in figure legend using either R or GraphPad

787 Prism 8 software (La Jolla, CA, USA).

\section{$788 \quad$ Data and software availability}

789 The extensive datasets presented in this manuscript are made available in Tables S1-S4. The

790 immunophenotypes are presented in Table S1C as frequencies of cell types and in Table S1B as`

791 fold changes relative to uninfected GF mice. The accession number for the gene expression raw

792 data reported in this paper is pending. 
bioRxiv preprint doi: https://doi.org/10.1101/2020.10.20.347286; this version posted October 20, 2020. The copyright holder for this preprint (which was not certified by peer review) is the author/funder, who has granted bioRxiv a license to display the preprint in perpetuity. It is made available under aCC-BY-NC-ND 4.0 International license.

A

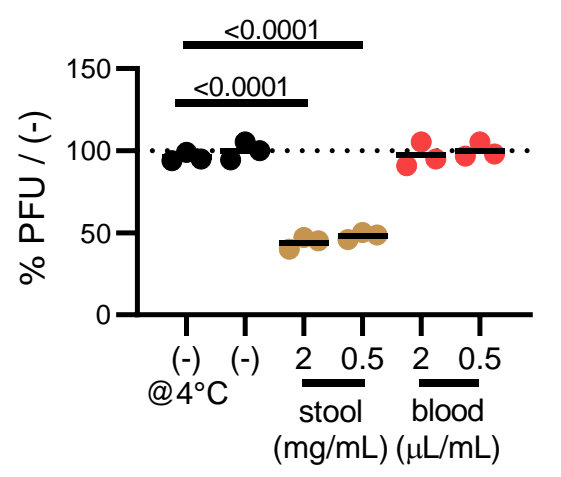

$\mathrm{B}$

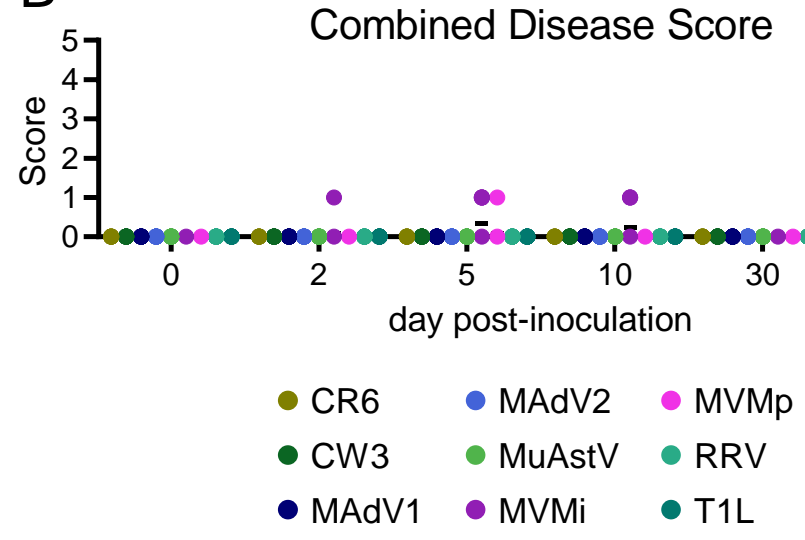

D

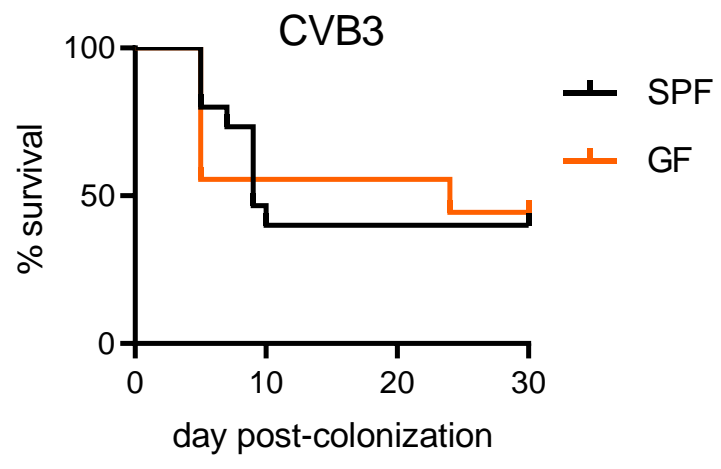

$E$

\begin{tabular}{|l|l|l|l|l|}
\cline { 2 - 5 } \multicolumn{1}{c|}{} & \multicolumn{2}{c|}{ Stool } & \multicolumn{2}{c|}{ Blood } \\
\cline { 2 - 5 } \multicolumn{1}{c|}{} & Peak titer & Duration & Peak titer & Duration \\
\hline CR6 & $\downarrow(0.048)$ & $=(0.999)$ & & \\
\hline CW3 & $=(0.381)$ & $\rightarrow(0.022)$ & & \\
\hline MAdV1 & $\uparrow(0.004)$ & $=(0.600)$ & $=(0.650)$ & $=(0.640)$ \\
\hline MAdV2 & $\downarrow(0.048)$ & $\rightarrow(0.037)$ & & \\
\hline MuAstV & $=(0.999)$ & $\rightarrow(0.003)$ & $=(0.279)$ & $\rightarrow(0.037)$ \\
\hline MVMi & $=(0.683)$ & $\rightarrow(0.002)$ & $=(0.460)$ & $=(0.150)$ \\
\hline MVMp & $=(0.153)$ & $\rightarrow(0.004)$ & & \\
\hline T1L & $\uparrow(0.048)$ & $=(0.999)$ & & \\
\hline
\end{tabular}

day post-colonization
C

GF
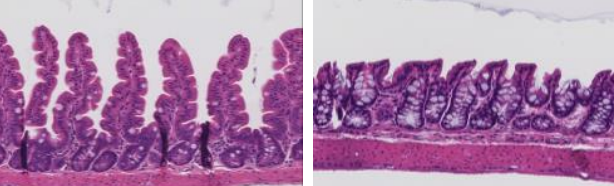

MDF

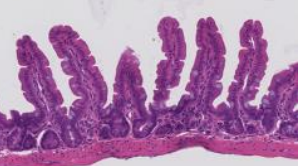

CR6
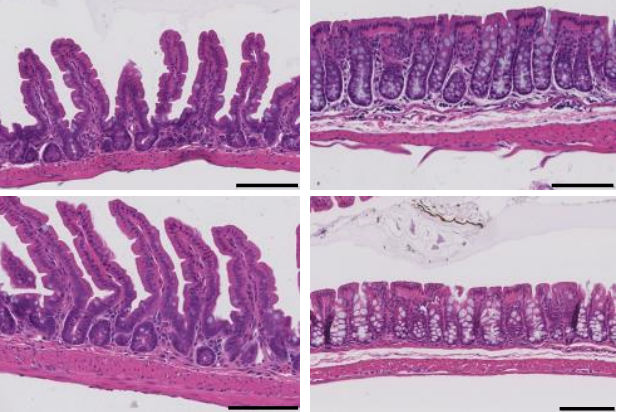

CW3
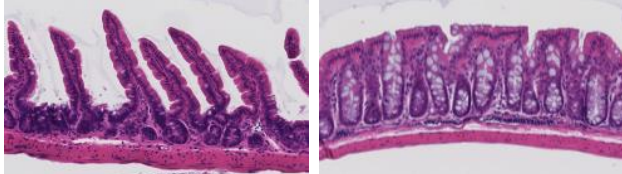

60 Yersinia

MAdV1
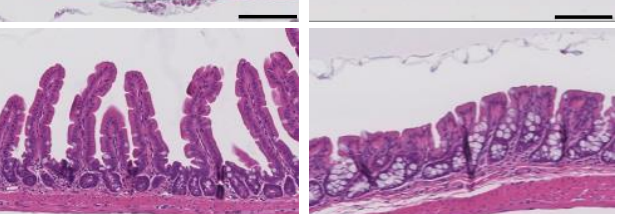

MAdV2
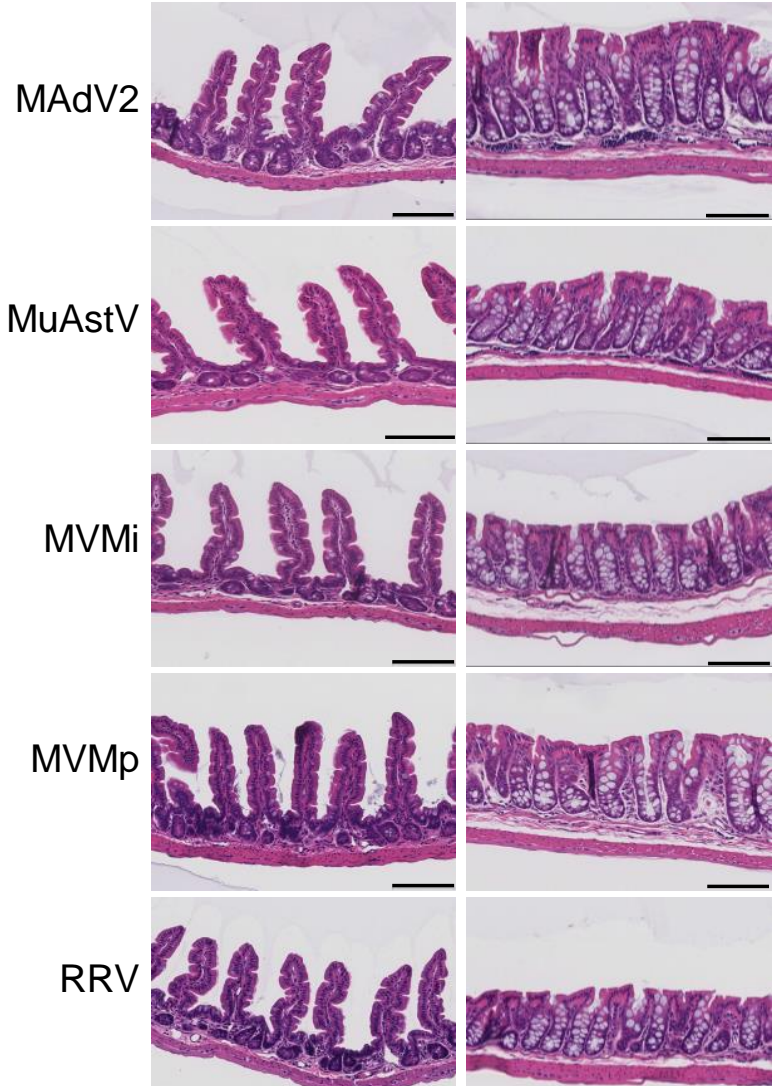

T1L
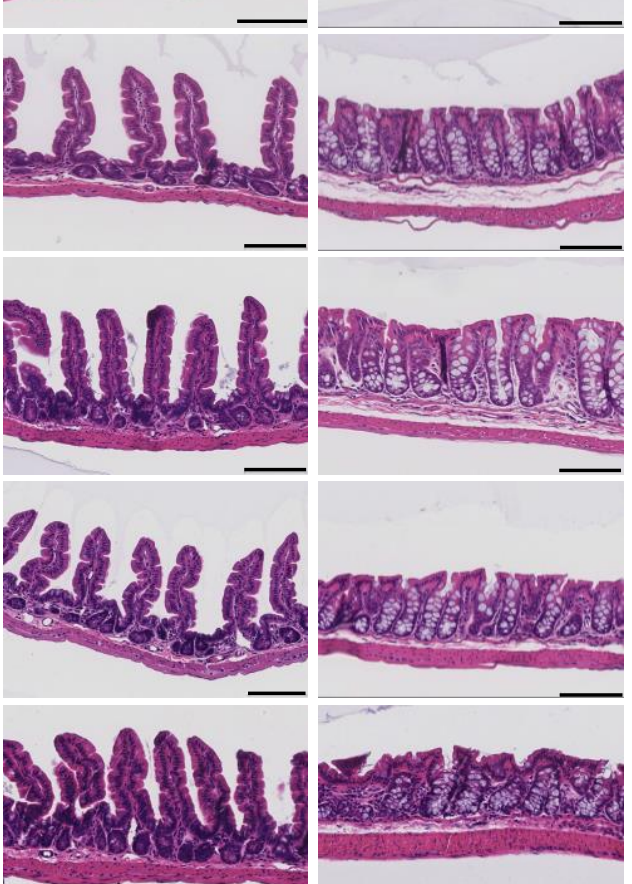


\section{Figure S1. Enteric Virus Infection in Conventional and GF Mice}

794 (A) Incubation of RRV at $37^{\circ} \mathrm{C}$ for $1 \mathrm{~h}$ with clarified stool lysate but not blood lead to a reduction

795 in plaque forming units (PFUs). Values were normalized to the number of plaques observed when

796 the same stock of RRV was kept at $4^{\circ} \mathrm{C}$ in parallel. Data are representative of two independent

797 experiments. Dots depict replicates from one representative experiment. Statistical significance

798 was calculated by ANOVA followed by Dunn's post-hoc analysis.

799 (B) GF mice inoculated with the enteric viruses shown in Figure 1 were scored at indicated days

800 post-inoculation (dpi) for diarrhea (0: no diarrhea, 2: watery stool), hunched posture (0: no

801 hunching, 2: hunched), and visible blood in the stool (0: no, 1: yes). As a reference, the combined

802 disease score is shown for four GF mice orally inoculated with Yersinia Pseudotubercolosis on

803 day 7 from two independent experiments.

804 (C) H\&E-stained sections of the small intestine (left) and colon (right) of GF mice at 28 dpi

805 indicating absence of overt inflammation. Bar indicates $100 \mu \mathrm{m}$.

806 (D) Survival of 15 conventional and 9 GF mice inoculated perorally with CVB3 from four 807 independent experiments.

808 (E) Time course of viral loads in stool and blood of conventional versus GF mice from Figure 1

809 were compared to identify significant differences in peak titer and duration. Statistical significance

810 for peak titer was calculated using a non-parametric Mann-Whitney test at the timepoint with the

811 highest viral titer in GF mice. Green upward arrow and red downward arrow refer to an increase

812 and decrease in viral titer in GF mice, respectively. Statistical significance for the duration of viral

813 shedding was calculated using a log-rank test. Green right-facing arrow refers to prolonged

814 detection of virus in GF mice. Gray boxes indicate conditions in which viruses were not detected

815 in the blood. Value in parentheses denote p-values. 
bioRxiv preprint doi: $h t t p s: / / d o i . o r g / 10.1101 / 2020.10 .20 .347286$; this version posted October 20,2020 . The copyright holder for this preprint (which was not certified by peer review) is the author/funder, who has granted bioRxiv a license to display the preprint in perpetuity. It is made available under aCC-BY-NC-ND 4.0 International license.

A

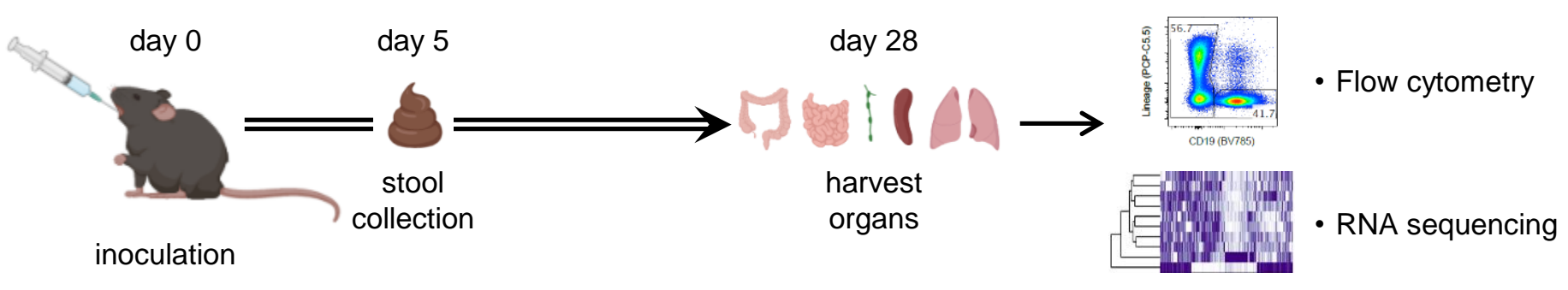

B
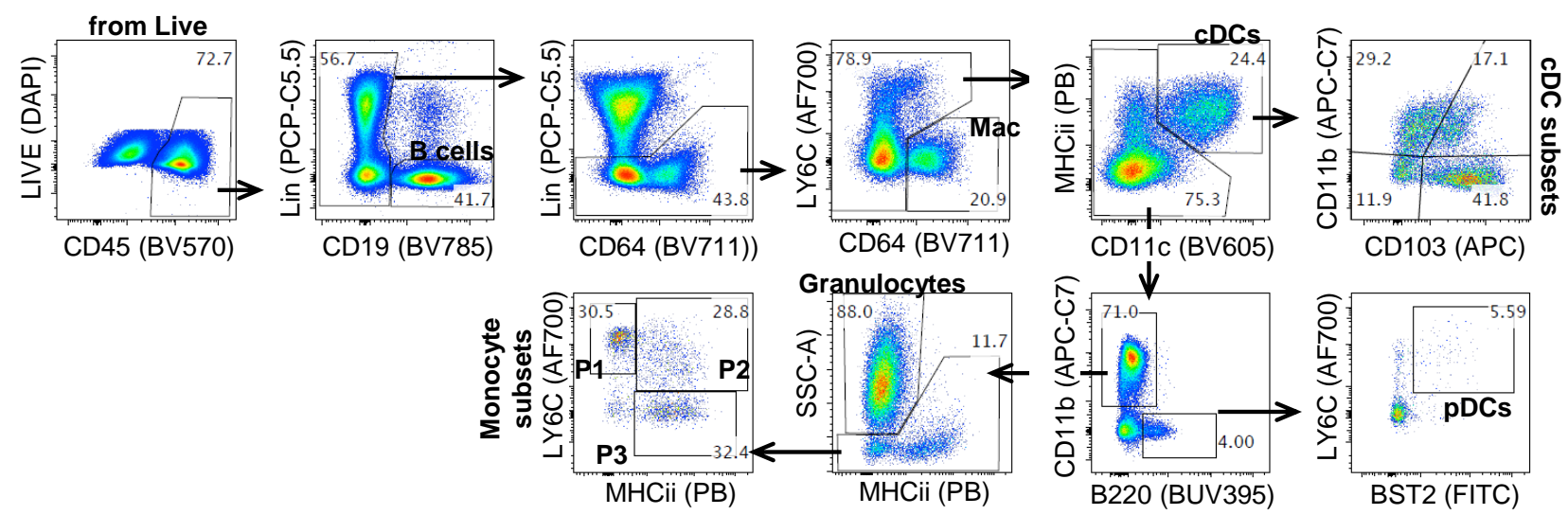

C
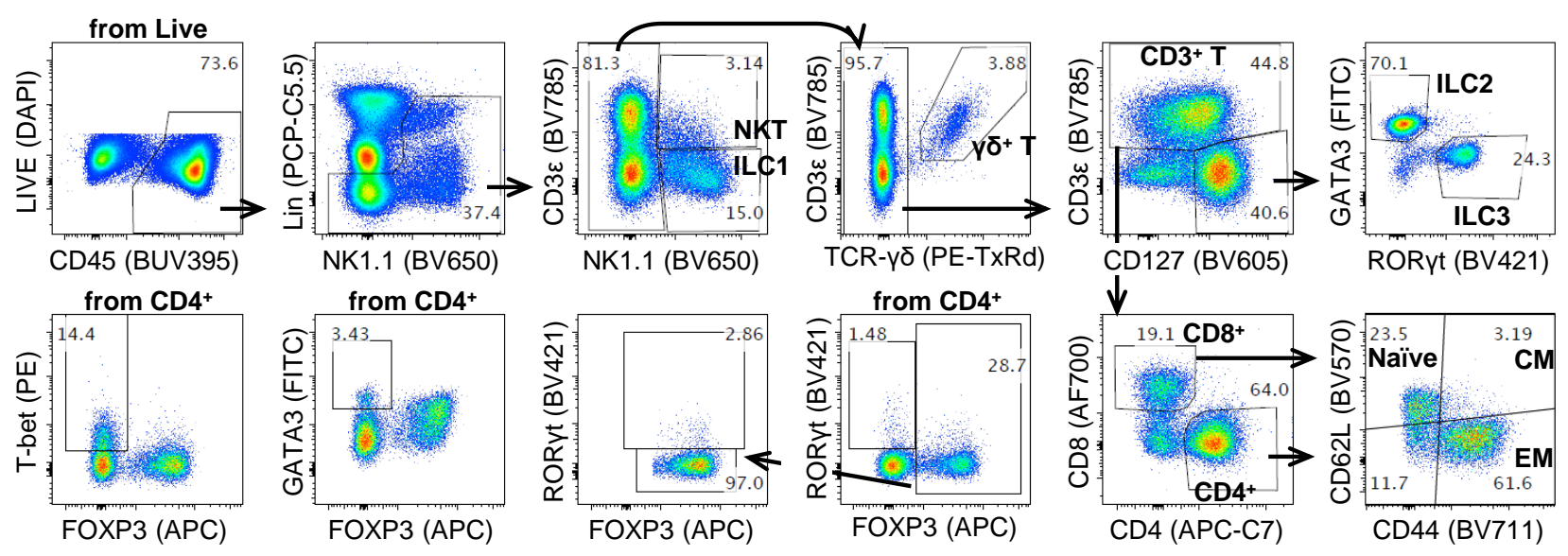

\section{D}
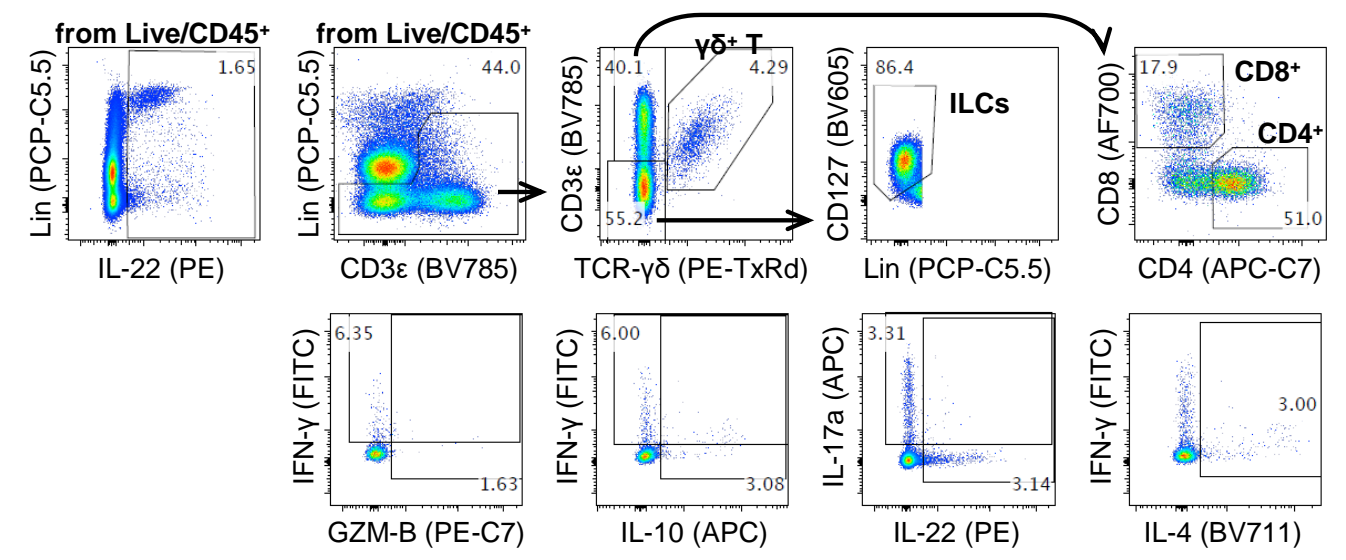


\section{Figure S2. Experimental Design and Gating Strategy}

817 (A) Experimental design for immune profiling of virus-infected mice. Five-to-six-week-old mice

818 were untreated or inoculated with viruses or bacteria. Four weeks after inoculation, effects on

819 immune cells and the transcriptome was evaluated. Five-to-eight mice were analyzed per

820 condition. To ensure that each condition was represented in at least two independent experiments,

821 results of 11 independent experiments with 8-12 mice are presented and include control untreated

822 GF mice in each independent experiment. Prepared using BioRender.com.

823 (B-D) Flow cytometry gating strategies for B cells and myeloid cells (B), T cells and ILCs (C,

824 transcription factors), and cytokine production (D). 
bioRxiv preprint doi: https://doi.org/10.1101/2020.10.20.347286; this version posted October 20, 2020. The copyright holder for this preprint (which was not certified by peer review) is the author/funder, who has granted bioRxiv a license to display the preprint in perpetuity. It is made available under aCC-BY-NC-ND 4.0 International license.

A

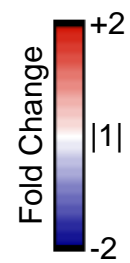

SI IEL

B cells

Macrophages

$\mathrm{CD} 11 \mathrm{~b}+\mathrm{CD} 103-\mathrm{cDCs}$

CD11b+CD103+ cDCs

CD11b-CD103+ CDCs

CD11b-CD103- CDCs

pDCs
Granulocytes

Monocyte P2

Monocyte P3

Monocyte P1

$\mathrm{CD} 3^{+} \mathrm{y} \bar{\delta}^{+}$T cells

$\mathrm{CD}^{+} \mathrm{T}$ cells

CD3 $3+\mathrm{CD} 4+\mathrm{T}$ cells

$\mathrm{FOXP3} 3^{+} \mathrm{CD} 4{ }^{+} \mathrm{T}$ cells

FOXP3 ${ }^{+} \mathrm{RORYt}^{+} \mathrm{CD}^{+} \mathrm{T}$ cells

FOXP3+RORyt CD4 ${ }^{+} T$ cells

GATA3+ CD4+ $T$ cells

Naïve CD4+ $T$ cells

Central memory CD $4^{+} T$ cells

Effector memory CD4 ${ }^{+} T$ cells

RORyt ${ }^{+} \mathrm{CD}^{+}{ }^{+} \mathrm{T}$ cells

Tbet $^{+}$CD $4^{+}+$cells

CD3 ${ }^{+} \mathrm{CD} 8+{ }^{+}+$cells

Naïve CD ${ }^{+} T$ cells

Central memory CD $8^{+} T$ cells

Effector memory CD8 ${ }^{+} \mathrm{T}$ cells

${ }^{1 L C C 2^{+}}$

Group 1 NLC

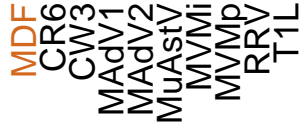

\section{Spleen}

B cells

CDCs

CD8+CD11b- CDCs

CD8-CD11b+ CDCS

Granulocytes

Monocyte Ly6c

Monocyte Ly6c ${ }^{+}$

$\mathrm{CD} 3^{+} \mathrm{y}^{+} \mathrm{T}$ cells

CD $3^{+} T$ cells

$\mathrm{CD}^{+}{ }^{+} \mathrm{CD} 4{ }^{+}+\mathrm{T}$ cells

$\mathrm{FOXP3}^{+} \mathrm{CD}^{+}+\mathrm{T}$ cells

FOXP3+RORyt ${ }^{+} \mathrm{CD}^{+}+\mathrm{T}$ cells

FOXP3+RORyt CD4+ + cells

GATA3+ CD4+ $T$ cells

Naïve CD4+ $T$ cells

Central memory CD4 ${ }^{+} T$ cells

Effector memory CD4+ ${ }^{+}$cells

RORyt ${ }^{+} \mathrm{CD}^{+}{ }^{+} \mathrm{T}$ cells

Tbet $^{+}$CD4+ $T$ cells

$\mathrm{CD}^{+}{ }^{+} \mathrm{CD} 8^{+}+\mathrm{T}$ cells

Naîve CD8 ${ }^{+} T$ cells

Central memory CD8 ${ }^{+} T$ cells

Effector memory CD8 ${ }^{+} T$ cells

Group 1 NLC



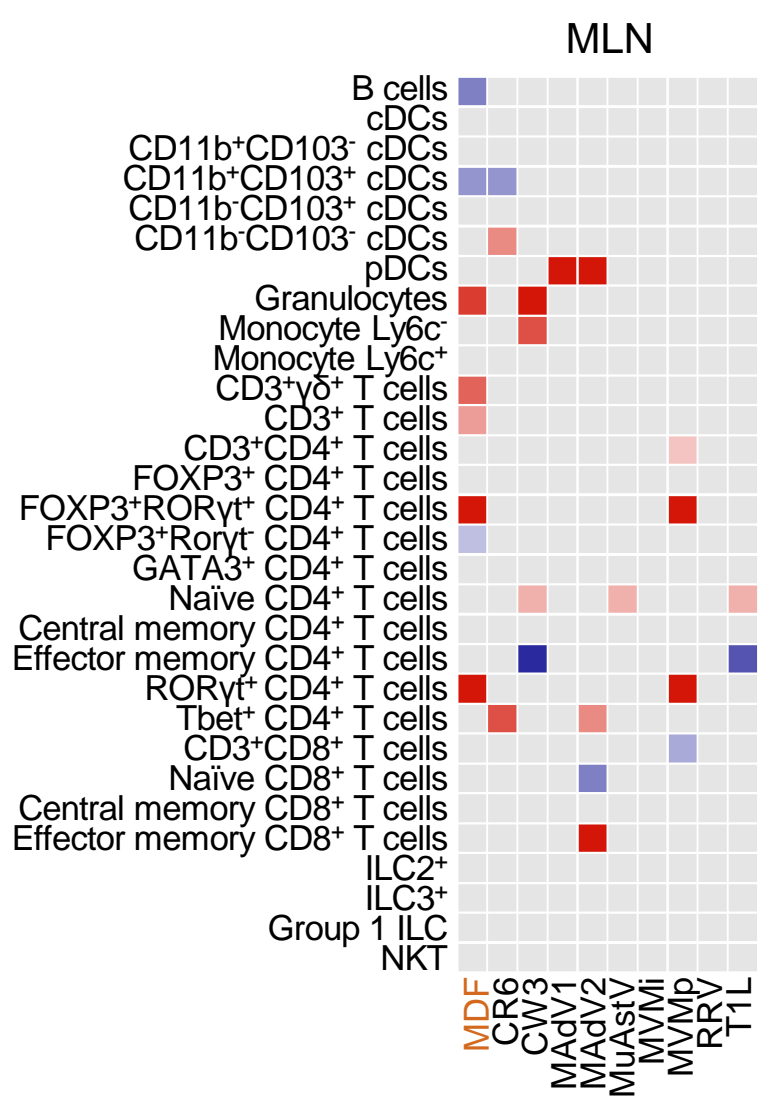

Lungs

Macrophages

CD11b+CD11c- Macs

CD11b-CD11c ${ }^{+}$Macs

cDCs

CD11b+CD103- cDCs

CD11b+CD103+ cDCs

CD11b-CD103+ CDCs

CD11b-CD103 cDCs

Granulocytes

Monocyte Ly6c

Monocyte Ly6c ${ }^{+}$

$\mathrm{CD}^{+} \mathrm{yO}^{+} \mathrm{T}$ cells

$\mathrm{CD} 3^{+} \mathrm{T}$ cells

CD3+CD4 $+T$ cells

$\mathrm{FOXP3}^{+} \mathrm{CD}^{+}+\mathrm{T}$ cells

FOXP3 ${ }^{+} \mathrm{RORYt}^{+} \mathrm{CD}^{+}+\mathrm{T}$ cells

FOXP3+RORyt CD4+ + cells

GATA3+ CD4+ $T$ cells

Naîve CD4 + T cells

Central memory CD4+ $\mathrm{T}$ cells

Effector memory CD4 ${ }^{+} T$ cells

$\mathrm{RORyt}^{+} \mathrm{CD} 4{ }^{+} \mathrm{T}$ cells

Tbet $^{+}$CD4 ${ }^{+} T$ cells

$\mathrm{CD}^{+}{ }^{+} \mathrm{CD} 8{ }^{+} \mathrm{T}$ cells

Naïve CD8+ T cells

Central memory CD $8^{+} T$ cells

Effector memory CD8 ${ }^{+} T$ cells

Group 11 NKC

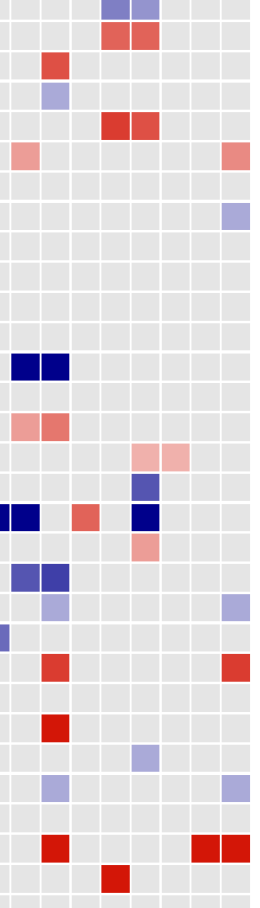

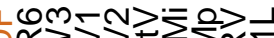

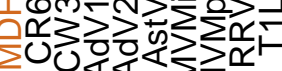
$\sum \sum \sum \Sigma \sum$

Figure S3 


\section{Figure S3. Enteric Viruses Promote Changes in Immune Cell Populations of Extra-Intestinal}

\section{Tissues}

827 Heatmap showing the average fold-change for each immune population relative to GF in IELs,

828 mLNs, spleen, and lungs with an FDR $<0.1$. Gray: FDR $>0.1$. 
bioRxiv preprint doi: https://doi.org/10.1101/2020.10.20.347286; this version posted October 20, 2020. The copyright holder for this preprint (which was not certified by peer review) is the author/funder, who has granted bioRxiv a license to display the preprint in perpetuity. It is made available under aCC-BY-NC-ND 4.0 International license.

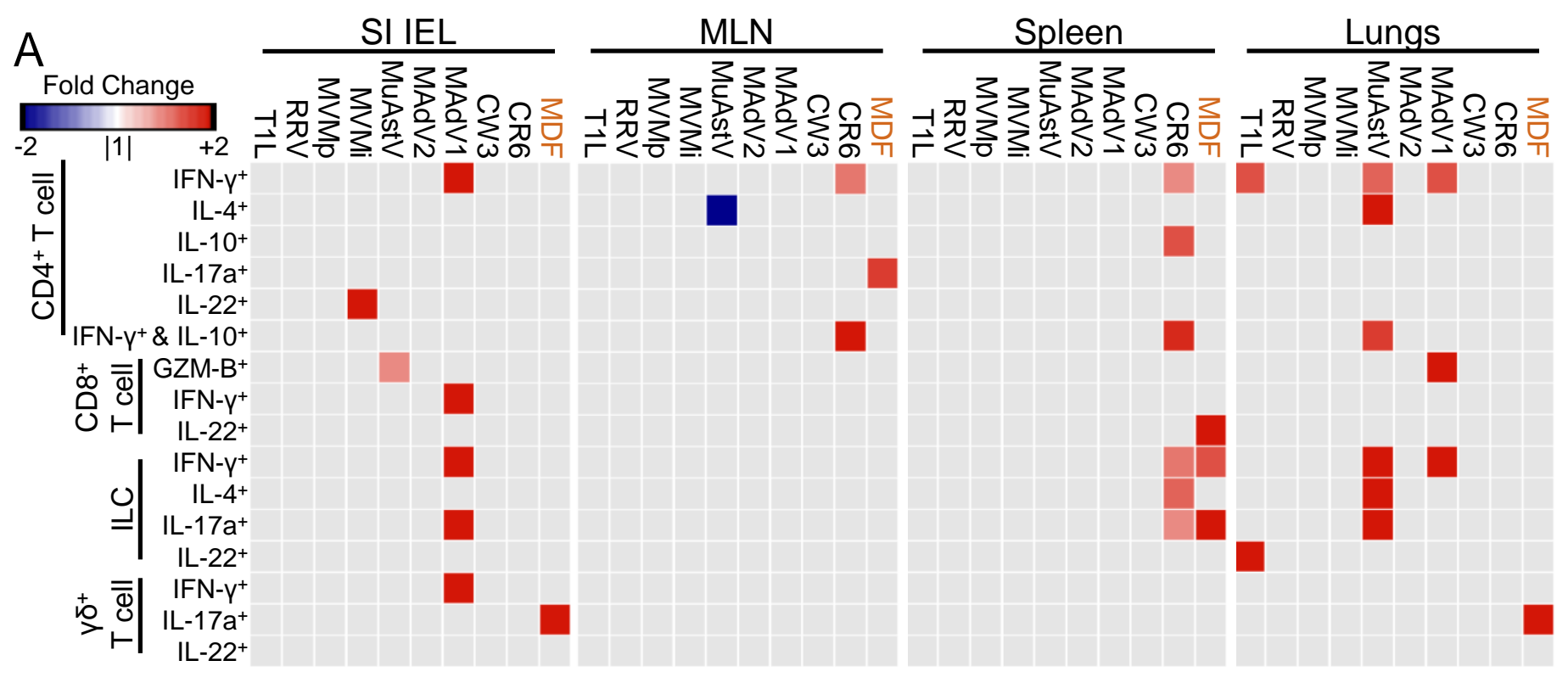

B

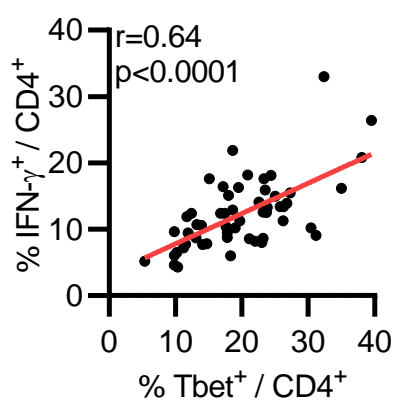

C

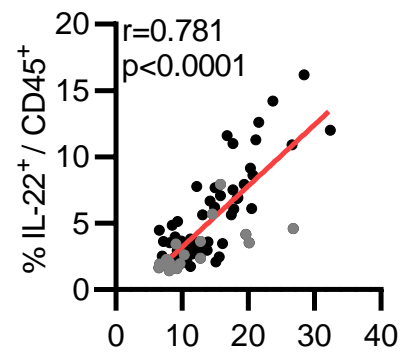

$\%$ granulocytes / CD45

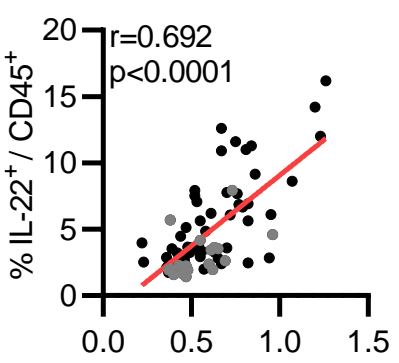

$\%$ monocyte P3 / CD45



$\%$ macrophages / CD45 ${ }^{+}$ 
829 Figure S4. Enteric Viruses Increase Cytokine Production by Immune Cells in Extra830 Intestinal Tissues

831 (A) Heatmaps showing average fold-change for cytokine-producing immune cell populations for

832 the indicated conditions relative to GF mice in IELs, mLNs, spleen, and lungs with an FDR < 0.1 .

833 Gray: FDR $>0.1$.

834 (B-C) Pearson correlation between the indicated population frequencies in cLP. Black dots: virus835 infected samples; gray dots: GF samples. 
bioRxiv preprint doi: https://doi.org/10.1101/2020.10.20.347286; this version posted October 20, 2020. The copyright holder for this preprint (which was not certified by peer review) is the author/funder, who has granted bioRxiv a license to display the preprint in perpetuity. It is made available under aCC-BY-NC-ND 4.0 International license.
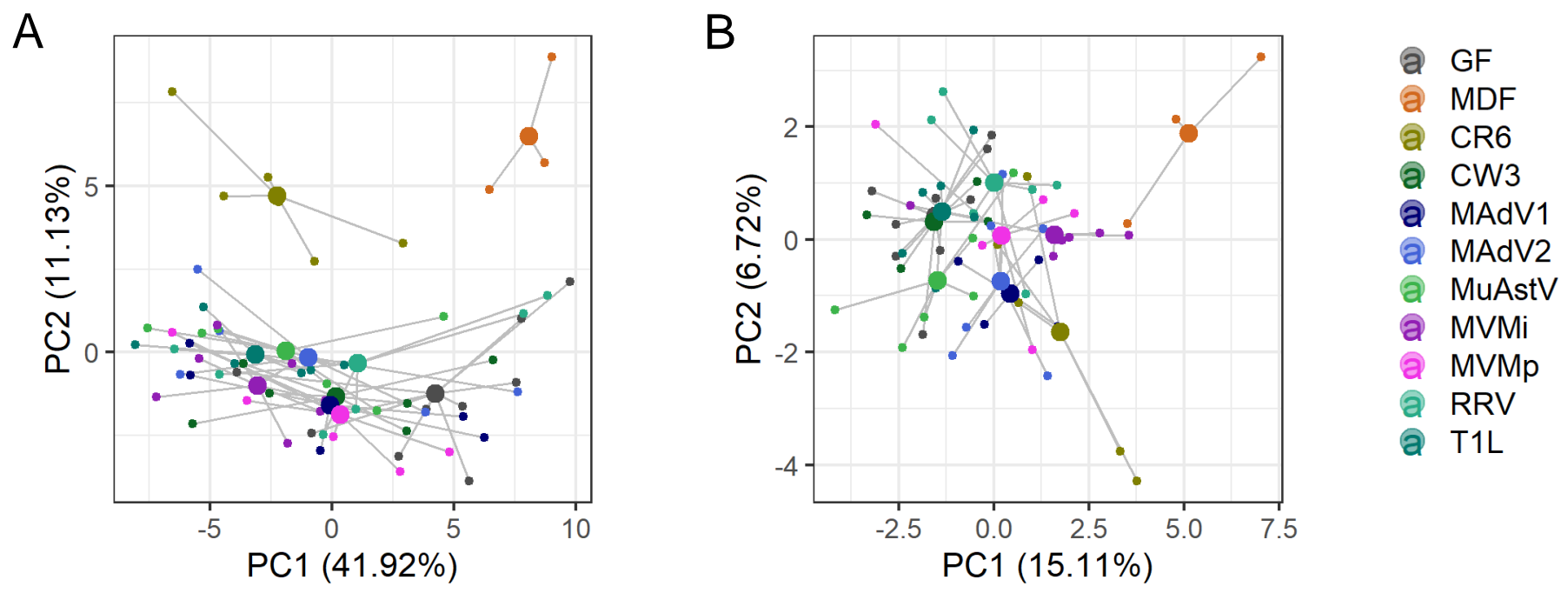

C

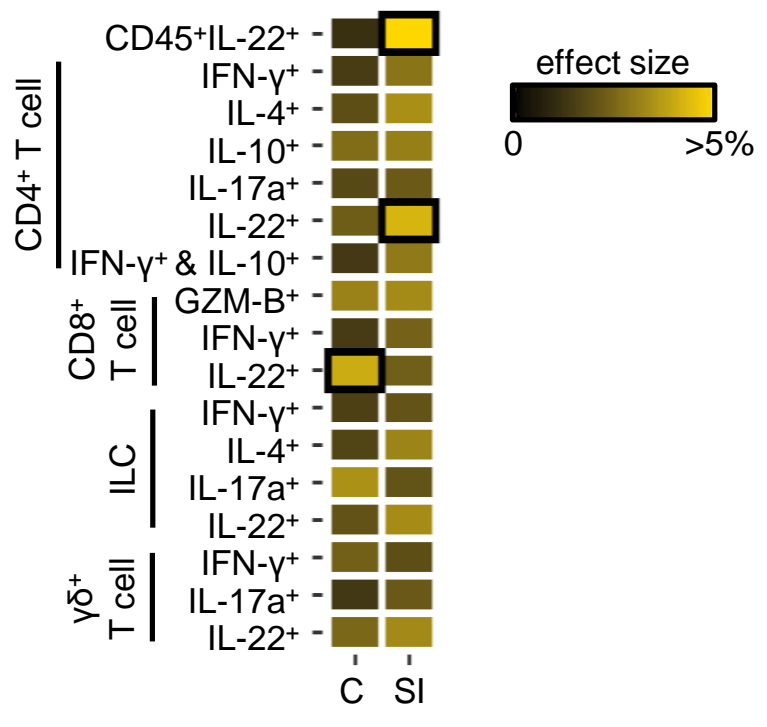




\section{Figure S5. Tissue Transcriptome Induced by Viral Infection}

837 (A-B) PCA clustering of the colonic (A) and small intestinal (B) DE genes. Samples inoculated

838 with the same microbe are connected by lines to the calculated group centroids.

839 (C) db-RDA indicating the individual effect size of the cytokine production frequencies obtained

840 by flow cytometry as explanatory variables of the DE gene variance in the colon and small

841 intestine. Black boxes indicate $\mathrm{p}<0.05$. 
bioRxiv preprint doi: https://doi.org/10.1101/2020.10.20.347286; this version posted October 20,2020. The copyright holder for this preprint (which was not certified by peer review) is the author/funder, who has granted bioRxiv a license to display the preprint in perpetuity. It is made available under aCC-BY-NC-ND 4.0 International license.

A
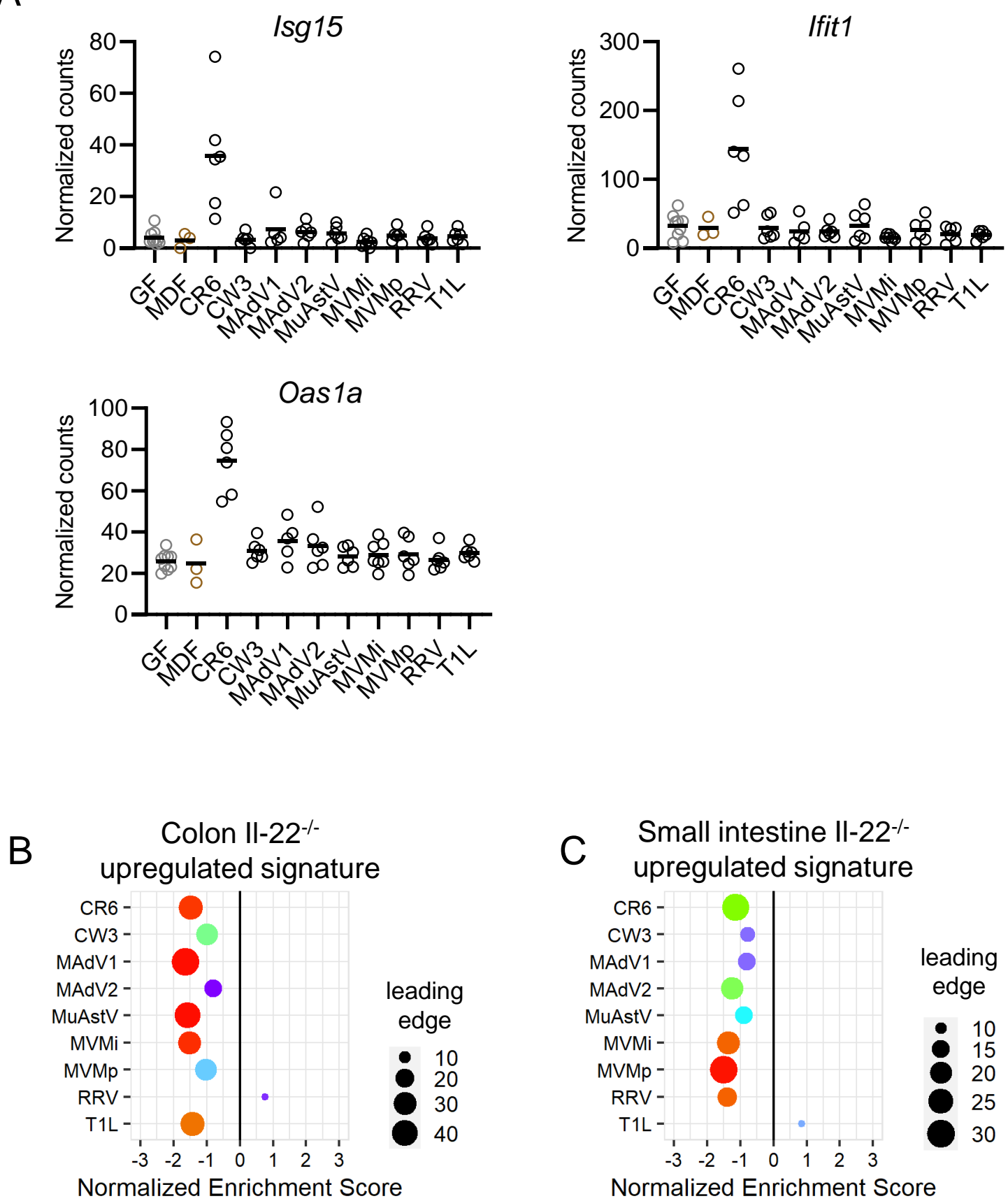

C Small intestine II-22-/-

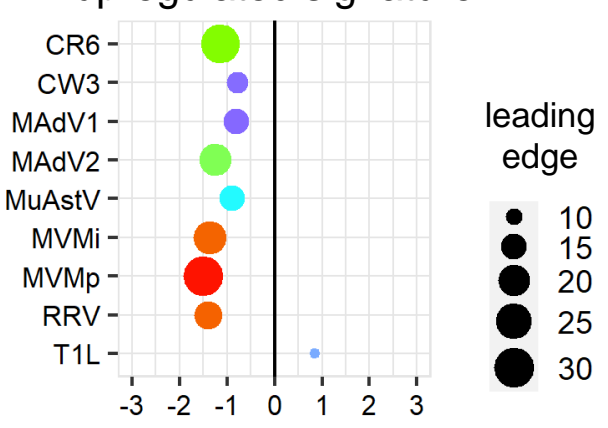

FDR

Normalized Enrichment Score 


\section{Figure S6. Expression of Interferon-Stimulated Genes and IL-22 Signature}

843 (A) DESeq2 transformed counts of the indicated representative interferon-stimulated genes (ISGs)

844 from RNA-Seq of the colon.

845 (B-C) Gene expression in the colon (B) and small intestine (C) from virus-infected mice were

846 analyzed for enrichment of transcripts upregulated in the intestines of IL-22-/- mice by GSEA. 
bioRxiv preprint doi: https://doi.org/10.1101/2020.10.20.347286; this version posted October 20,2020 . The copyright holder for this preprint (which was not certified by peer review) is the author/funder, who has granted bioRxiv a license to display the preprint in perpetuity. It is made available under aCC-BY-NC-ND 4.0 International license.

\begin{tabular}{|l|l|l|}
\hline \multirow{2}{*}{ MAdV1 } & \multicolumn{1}{|c|}{ Primer Forward } & \multicolumn{1}{c|}{ Primer Reverse } \\
\hline \multirow{2}{*}{ MAdV2 } & GCACTCCATGGCAGGATTCT & \multicolumn{1}{|c|}{ GGTCGAAGCAGACGGTTCTTC } \\
\cline { 2 - 3 } & TaqMan Probe: TACTGCCACTTCTGC & \multicolumn{2}{|c|}{ GTCAGACAACTTCCCAGGGT } \\
\hline \multirow{2}{*}{ MuAstV } & GCTGACGCCCATATCCAAAT & GTGTCACTAACGCGCACCTTTTCA \\
\cline { 2 - 3 } MNV & TaqMan Probe: CAGGTTTGAGTCCCGGTAGCGTTC \\
\hline \multirow{2}{*}{ MVM } & TACATCGAGCGGGTGGTCGC & GCGCTGCGCCATCACTC \\
\hline \multirow{2}{*}{$16 \mathrm{~s}$} & CACGCCACCGATCTGTTCTG & ACTGGTTTACTTGCTGTCC \\
\cline { 2 - 3 } & TaqMan Probe: CGCTTTGGAACAATG & \multicolumn{2}{|l}{ TTACCGCGGCTGCTGGC } \\
\cline { 2 - 3 } & AGTTTGCCATGCTATTTGC & TaqMan Probe: ATTTCTTTTGCCTCCTTGTCTGTTT \\
\hline
\end{tabular}

\section{Table S5: Primers and probes used in the study.}




\begin{tabular}{|c|c|c|c|}
\hline Antibodies & Source & clone & Identifier \\
\hline $\begin{array}{l}\text { Alexa Fluor } 488 \text { anti-mouse CD317 (BST2, } \\
\text { PDCA-1) Antibody }\end{array}$ & Biolegend & 927 & CAT\#127012; RRID: AB_1953287 \\
\hline $\begin{array}{l}\text { Alexa Fluor } 488 \text { anti-mouse GATA3 } \\
\text { Antibody }\end{array}$ & $\mathrm{BD}$ & L50-823 & СAT\#560163 \\
\hline Alexa Fluor 488 anti-mouse IFN-y Antibody & Biolegend & XMG1.2 & CAT\#505813; RRID: AB_493312 \\
\hline $\begin{array}{l}\text { PerCP/Cyanine5.5 anti-mouse NK-1.1 } \\
\text { Antibody }\end{array}$ & Biolegend & PK136 & CAT\#108728; RRID: AB_2132705 \\
\hline $\begin{array}{l}\text { PerCP/Cyanine5.5 anti-mouse CD90.2 } \\
\text { (Thy-1.2) Antibody }\end{array}$ & Biolegend & $53-2.1$ & CAT\#140322; RRID: AB_2562696 \\
\hline $\begin{array}{l}\text { PerCP/Cyanine5.5 anti-mouse/human } \\
\text { CD11b Antibody }\end{array}$ & Biolegend & $\mathrm{M} 1 / 70$ & CAT\#101228; RRID: AB_893232 \\
\hline $\begin{array}{l}\text { PerCP/Cyanine5.5 anti-mouse CD11c } \\
\text { Antibody }\end{array}$ & Biolegend & N418 & CAT\#117328; RRID: AB_2129641 \\
\hline $\begin{array}{l}\text { PerCP/Cyanine5.5 anti-mouse Ly-6G/Ly-6C } \\
\text { (Gr-1) Antibody }\end{array}$ & Biolegend & RB6-8C5 & CAT\#108428; RRID: AB_893558 \\
\hline PerCP/Cyanine5.5 anti-mouse CD19 & eBioscience & eBio1D3 & CAT\#45-0193-82; RRID: AB_1106999 \\
\hline $\begin{array}{l}\text { PerCP/Cyanine5.5 anti-mouse TER- } \\
\text { 119/Erythroid Cells Antibody }\end{array}$ & Biolegend & Ter-119 & CAT\#116228; RRID: AB_893636 \\
\hline PE anti-T-bet Antibody & Biolegend & 4B10 & CAT\#644810; RRID: AB_2200542 \\
\hline PE anti-mouse IL-22 Antibody & eBioscience & 1H8PWSR & CAT\#12-7221-82; RRID: AB_10597428 \\
\hline $\begin{array}{l}\text { PE-CF594 anti-mouse үס T-Cell Receptor } \\
\text { Antibody }\end{array}$ & $\mathrm{BD}$ & GL3 & CAT\#563532. \\
\hline PE/Cyanine7 anti-mouse F4/80 Antibody & Biolegend & BM8 & CAT\#123114; RRID: AB_893478 \\
\hline $\begin{array}{l}\text { PE/Cyanine7 anti-mouse Granzyme B } \\
\text { Antibody }\end{array}$ & eBioscience & NGZB & CAT\#25-8898-82; RRID: AB_10853339 \\
\hline APC anti-mouse CD8a Antibody & Biolegend & $53-6.7$ & CAT\#100712; RRID: AB_312751 \\
\hline APC anti-mouse CD103 Antibody & Biolegend & $2 \mathrm{E} 7$ & CAT\#121414; RRID: AB_1227502 \\
\hline APC anti-mouse FOXP3 Antibody & eBioscience & FJK-16s & $\begin{array}{l}\text { CAT\#17-5773-82; RRID: } \\
\text { AB_AB_469457 }\end{array}$ \\
\hline APC anti-mouse IL-17A Antibody & Biolegend & $\begin{array}{c}\text { TC11- } \\
18 \mathrm{H} 10.1\end{array}$ & CAT\#506916; RRID: AB_536018 \\
\hline Alexa Fluor 700 anti-mouse Ly-6C Antibody & $\mathrm{BD}$ & AL-21 & CAT\#561237. \\
\hline Alexa Fluor 700 anti-mouse CD8a Antibody & Biolegend & $53-6.7$ & CAT\#100730; RRID: AB_493703 \\
\hline $\begin{array}{l}\text { APC/Cyanine7 anti-mouse/human CD11b } \\
\text { Antibody }\end{array}$ & Biolegend & $\mathrm{M} 1 / 70$ & CAT\#101226; RRID: AB_830642 \\
\hline APC/Cyanine7 anti-mouse CD4 Antibody & Biolegend & GK1.5 & CAT\#100414; RRID: AB_312699 \\
\hline Pacific Blue anti-mouse I-A/I-E Antibody & Biolegend & M5/114.15.2 & CAT\#107620; RRID: AB_493527 \\
\hline BV421 anti-mouse RORyt Antibody & $\mathrm{BD}$ & Q31-378 & CAT\#562894. \\
\hline BV421 anti-mouse IL-10 Antibody & $\mathrm{BD}$ & JES5-16E3 & CAT\#566295. \\
\hline $\begin{array}{l}\text { Brilliant Violet } 570 \text { anti-mouse CD45 } \\
\text { Antibody }\end{array}$ & Biolegend & 30-F11 & CAT\#103136; RRID: AB_2562612 \\
\hline $\begin{array}{l}\text { Brilliant Violet } 570 \text { anti-mouse CD62L } \\
\text { Antibody }\end{array}$ & Biolegend & MEL-14 & CAT\#104433; RRID: AB_10900262 \\
\hline $\begin{array}{l}\text { Brilliant Violet } 605 \text { anti-mouse CD11c } \\
\text { Antibody }\end{array}$ & Biolegend & N418 & CAT\#117334; RRID: AB_2562415 \\
\hline $\begin{array}{l}\text { Brilliant Violet } 605 \text { anti-mouse CD127 (IL- } \\
\text { 7Ra) Antibody }\end{array}$ & Biolegend & A7R34 & CAT\#135041; RRID: AB_2572047 \\
\hline
\end{tabular}




\begin{tabular}{|c|c|c|c|}
\hline $\begin{array}{l}\text { Brilliant Violet } 650^{\mathrm{TM}} \text { anti-mouse NK-1.1 } \\
\text { Antibody }\end{array}$ & Biolegend & PK136 & CAT\#108736; RRID: AB_2563159 \\
\hline $\begin{array}{l}\text { Brilliant Violet } 711 \text { anti-mouse CD64 (FcyRl) } \\
\text { Antibody }\end{array}$ & Biolegend & $X 54-5 / 7.1$ & CAT\#139311; RRID: AB_2563846 \\
\hline $\begin{array}{l}\text { Brilliant Violet } 711 \text { anti-mouse/human CD44 } \\
\text { Antibody }\end{array}$ & Biolegend & IM7 & CAT\#103057; RRID: AB_2564214 \\
\hline Brilliant Violet 711 anti-mouse IL-4 Antibody & $\mathrm{BD}$ & 11B11 & CAT\#564005. \\
\hline $\begin{array}{l}\text { Brilliant Violet } 786 \text { anti-mouse CD3e } \\
\text { Antibody }\end{array}$ & BD & $145-2 C 11$ & CAT\#564379. \\
\hline $\begin{array}{l}\text { Super Bright } 780 \text { anti-mouse CD19 } \\
\text { Antibody }\end{array}$ & eBioscience & $1 \mathrm{D} 3$ & CAT\#78-0193-82; RRID: AB_2722936 \\
\hline BUV395 anti-mouse CD45 Antibody & $\mathrm{BD}$ & 30-F11 & CAT\#564279. \\
\hline BUV395 anti-mouse CD45R/B220 Antibody & $\mathrm{BD}$ & RA3-6B2 & CAT\#563793. \\
\hline Zombie UV Fixable Viability Kit & Biolegend & CAT\#50581 & 3; RRID: AB_493312 \\
\hline
\end{tabular}

\section{Table S6: List of the flow cytometry antibodies used in this study.}




\section{$\underline{\text { References }}$}

Abt, M.C., Buffie, C.G., Sušac, B., Becattini, S., Carter, R.A., Leiner, I., Keith, J.W., Artis, D., Osborne, L.C., and Pamer, E.G. (2016). TLR-7 activation enhances IL-22-mediated colonization resistance against vancomycin-resistant enterococcus. Science Translational Medicine 8.

Atarashi, K., Tanoue, T., Shima, T., Imaoka, A., Kuwahara, T., Momose, Y., Cheng, G., Yamasaki, S., Saito, T., Ohba, Y., et al. (2011). Induction of colonic regulatory T cells by indigenous Clostridium species. Science (New York, N.Y.) 331, 337-341.

Axelrad, J.E., Joelson, A., Green, P.H.R., Lawlor, G., Lichtiger, S., Cadwell, K., and Lebwohl, B. (2018). Enteric Infections Are Common in Patients with Flares of Inflammatory Bowel Disease. The American Journal of Gastroenterology 113, 1530-1539.

Axelrad, J.E., Olén, O., Askling, J., Lebwohl, B., Khalili, H., Sachs, M.C., and Ludvigsson, J.F. (2019). Gastrointestinal Infection Increases Odds of Inflammatory Bowel Disease in a Nationwide Case-Control Study. Clinical Gastroenterology and Hepatology: The Official Clinical Practice Journal of the American Gastroenterological Association 17, 1311-1322.e7.

Baldridge, M.T., Nice, T.J., McCune, B.T., Yokoyama, C.C., Kambal, A., Wheadon, M., Diamond, M.S., Ivanova, Y., Artyomov, M., and Virgin, H.W. (2015). Commensal microbes and interferon- $\lambda$ determine persistence of enteric murine norovirus infection. Science 347, 266-269.

Basic, M., Keubler, L.M., Buettner, M., Achard, M., Breves, G., Schröder, B., Smoczek, A., Jörns, A., Wedekind, D., Zschemisch, N.H., et al. (2014). Norovirus triggered microbiota-driven mucosal inflammation in interleukin 10-deficient mice. Inflammatory Bowel Diseases 20, 431443.

Beura, L.K., Hamilton, S.E., Bi, K., Schenkel, J.M., Odumade, O.A., Casey, K.A., Thompson, recapitulates adult human immune traits in laboratory mice. Nature 532, 512-516.

Bloom, S.M., Bijanki, V.N., Nava, G.M., Sun, L., Malvin, N.P., Donermeyer, D.L., Dunne, W.M., Allen, P.M., and Stappenbeck, T.S. (2011). Commensal Bacteroides species induce colitis in host-genotype-specific fashion in a mouse model of inflammatory bowel disease. Cell Host \& Microbe 9, 390-403.

878 in Immunology 4, 402. 
Bolsega, S., Basic, M., Smoczek, A., Buettner, M., Eberl, C., Ahrens, D., Odum, K., Stecher, B., and Bleich, A. (2019). Composition of the Intestinal Microbiota Determines the Outcome of Virus-Triggered Colitis in Mice. Frontiers in Immunology 10.

Bouziat, R., Hinterleitner, R., Brown, J.J., Stencel-Baerenwald, J.E., Ikizler, M., Mayassi, T.,

Meisel, M., Kim, S.M., Discepolo, V., Pruijssers, A.J., et al. (2017). Reovirus infection triggers

inflammatory responses to dietary antigens and development of celiac disease. Science 356, 4450.

Bouziat, R., Biering, S.B., Kouame, E., Sangani, K.A., Kang, S., Ernest, J.D., Varma, M., Inflammatory Responses to Dietary Antigens. Cell Host \& Microbe 24, 677-688.e5.

Broggi, A., Tan, Y., Granucci, F., and Zanoni, I. (2017). IFN- $\lambda$ suppresses intestinal inflammation by non-translational regulation of neutrophil function. Nature Immunology 18 , 1084-1093.

Brugiroux, S., Beutler, M., Pfann, C., Garzetti, D., Ruscheweyh, H.J., Ring, D., Diehl, M., Herp, S., Lötscher, Y., Hussain, S., et al. (2016). Genome-guided design of a defined mouse microbiota that confers colonization resistance against Salmonella enterica serovar Typhimurium. Nature Microbiology 2.

Cadwell, K., Liu, J.Y., Brown, S.L., Miyoshi, H., Loh, J., Lennerz, J.K., Kishi, C., Kc, W.,

903 Cortez, V., Boyd, D.F., Crawford, J.C., Sharp, B., Livingston, B., Rowe, H.M., Davis, A., 904 Alsallaq, R., Robinson, C.G., Vogel, P., et al. (2020). Astrovirus infects actively secreting goblet 905 cells and alters the gut mucus barrier. Nature Communications 11, 2097.

906 Drescher, K.M., von Herrath, M., and Tracy, S. (2015). Enteroviruses, hygiene and type 1 907 diabetes: toward a preventive vaccine. Reviews in Medical Virology 25, 19-32.

908 Fischbach, M.A. (2018). Microbiome: Focus on Causation and Mechanism. Cell 174, 785-790. 
Geva-Zatorsky, N., Sefik, E., Kua, L., Pasman, L., Tan, T.G., Ortiz-Lopez, A., Yanortsang, T.B., Yang, L., Jupp, R., Mathis, D., et al. (2017). Mining the Human Gut Microbiota for

911 Immunomodulatory Organisms. Cell 168, 928-943.e11.

912 Godec, J., Tan, Y., Liberzon, A., Tamayo, P., Bhattacharya, S., Butte, A.J., Mesirov, J.P., and 913 Haining, W.N. (2016). Compendium of Immune Signatures Identifies Conserved and Species-

914 Specific Biology in Response to Inflammation. Immunity 44, 194-206.

915 Gopinath, S., Kim, M. v., Rakib, T., Wong, P.W., van Zandt, M., Barry, N.A., Kaisho, T.,

916 Goodman, A.L., and Iwasaki, A. (2018). Topical application of aminoglycoside antibiotics

917 enhances host resistance to viral infections in a microbiota-independent manner. Nature 918 Microbiology 3, 611-621.

919 Grau, K.R., Zhu, S., Peterson, S.T., Helm, E.W., Philip, D., Phillips, M., Hernandez, A., Turula, 920 H., Frasse, P., Graziano, V.R., et al. (2020). The intestinal regionalization of acute norovirus 921 infection is regulated by the microbiota via bile acid-mediated priming of type III interferon. 922 Nature Microbiology 5, 84-92.

923 Griffin, D.E. (2020). Measles virus persistence and its consequences. Current Opinion in 924 Virology 41, 46-51.

925 Gronke, K., Hernández, P.P., Zimmermann, J., Klose, C.S.N., Kofoed-Branzk, M., Guendel, 926 F., Witkowski, M., Tizian, C., Amann, L., Schumacher, F., et al. (2019). Interleukin-22 protects 927 intestinal stem cells against genotoxic stress. Nature 566, 249-253.

928 Hall, A.B., Yassour, M., Sauk, J., Garner, A., Jiang, X., Arthur, T., Lagoudas, G.K., Vatanen, 929 T., Fornelos, N., Wilson, R., et al. (2017). A novel Ruminococcus gnavus clade enriched in 930 inflammatory bowel disease patients. Genome Medicine 9, 103.

931 Häringer, B., Lozza, L., Steckel, B., and Geginat, J. (2009). Identification and Characterization 932 of IL-10/IFN-gamma-producing Effector-Like T Cells With Regulatory Function in Human 933 Blood. The Journal of Experimental Medicine 206, 1009-1017.

934 Honda, K., and Littman, D.R. (2012). The Microbiome in Infectious Disease and Inflammation. 935 Annual Review of Immunology 30, 759-795.

936 Hooper, L. v, Wong, M.H., Thelin, A., Hansson, L., Falk, P.G., and Gordon, J.I. (2001). 937 Molecular analysis of commensal host-microbial relationships in the intestine. Science (New York, $938 \quad$ N.Y.) $291,881-884$. 
Ingle, H., Lee, S., Ai, T., Orvedahl, A., Rodgers, R., Zhao, G., Sullender, M., Peterson, S.T.,

Locke, M., Liu, T.C., et al. (2019). Viral complementation of immunodeficiency confers protection against enteric pathogens via interferon- $\lambda$. Nature Microbiology 4, 1120-1128.

942 Ivanov, I.I., Atarashi, K., Manel, N., Brodie, E.L., Shima, T., Karaoz, U., Wei, D., Goldfarb, 943 K.C., Santee, C.A., Lynch, S. v, et al. (2009). Induction of intestinal Th17 cells by segmented 944 filamentous bacteria. Cell 139, 485-498.

945 Kane, M., Case, L.K., Kopaskie, K., Kozlova, A., MacDearmid, C., Chervonsky, A. v, and 946 Golovkina, T. v (2011). Successful transmission of a retrovirus depends on the commensal 947 microbiota. Science 334, 245-249.

948 Keir, M.E., Yi, T., Lu, T.T., and Ghilardi, N. (2020). The role of IL-22 in intestinal health and 949 disease. Journal of Experimental Medicine 217.

950 Kernbauer, E., Ding, Y., and Cadwell, K. (2014). An enteric virus can replace the beneficial 951 function of commensal bacteria. Nature 516, 94-98.

952 Kim, Y.-G., Park, J.-H., Reimer, T., Baker, D.P., Kawai, T., Kumar, H., Akira, S., Wobus, C., and Núñez, G. (2011). Viral infection augments Nod1/2 signaling to potentiate lethality associated with secondary bacterial infections. Cell Host \& Microbe 9, 496-507.

Kuss, S.K., Best, G.T., Etheredge, C.A., Pruijssers, A.J., Frierson, J.M., Hooper, L. v., 956 Dermody, T.S., and Pfeiffer, J.K. (2011). Intestinal Microbiota Promote Enteric Virus Replication 957 and Systemic Pathogenesis. Science 334, 249-252.

958 Lee, S., Liu, H., Wilen, C.B., Sychev, Z.E., Desai, C., Hykes, B.L., Orchard, R.C., McCune, 959 B.T., Kim, K.-W., Nice, T.J., et al. (2019). A Secreted Viral Nonstructural Protein Determines 960 Intestinal Norovirus Pathogenesis. Cell Host \& Microbe 25, 845-857.e5.

961 Liang, G., Zhao, C., Zhang, H., Mattei, L., Sherrill-Mix, S., Bittinger, K., Kessler, L.R., Wu, 962 G.D., Baldassano, R.N., DeRusso, P., et al. (2020). The stepwise assembly of the neonatal virome 963 is modulated by breastfeeding. Nature 581, 470-474.

964 Lim, E.S., Zhou, Y., Zhao, G., Bauer, I.K., Droit, L., Ndao, I.M., Warner, B.B., Tarr, P.I., 965 Wang, D., and Holtz, L.R. (2015). Early life dynamics of the human gut virome and bacterial 966 microbiome in infants. Nature Medicine 21, 1228-1234.

967 Lin, J. da, Devlin, J.C., Yeung, F., McCauley, C., Leung, J.M., Chen, Y.H., Cronkite, A., 968 Hansen, C., Drake-Dunn, C., Ruggles, K. v., et al. (2020). Rewilding Nod2 and Atg1611 Mutant 
Mice Uncovers Genetic and Environmental Contributions to Microbial Responses and Immune Cell Composition. Cell Host and Microbe 27, 830-840.e4.

971 Liu, L., Gong, T., Tao, W., Lin, B., Li, C., Zheng, X., Zhu, S., Jiang, W., and Zhou, R. (2019).

972 Commensal viruses maintain intestinal intraepithelial lymphocytes via noncanonical RIG-I 973 signaling. Nature Immunology 20, 1681-1691.

974 Matsuzawa-Ishimoto, Y., Shono, Y., Gomez, L.E., Hubbard-Lucey, V.M., Cammer, M., Neil,

975 J., Dewan, M.Z., Lieberman, S.R., Lazrak, A., Marinis, J.M., et al. (2017). Autophagy protein 976 ATG16L1 prevents necroptosis in the intestinal epithelium. The Journal of Experimental Medicine $977 \quad 214,3687-3705$.

978 Matsuzawa-Ishimoto, Y., Hine, A., Shono, Y., Rudensky, E., Lazrak, A., Yeung, F., Neil, J.A., 979 Yao, X., Chen, Y.-H., Heaney, T., et al. (2020). An intestinal organoid-based platform that 980 recreates susceptibility to T-cell-mediated tissue injury. Blood 135, 2388-2401.

981 Mazmanian, S.K., Liu, C.H., Tzianabos, A.O., and Kasper, D.L. (2005). An 982 immunomodulatory molecule of symbiotic bacteria directs maturation of the host immune system. 983 Cell 122, 107-118.

984 Neil, J.A., Matsuzawa-Ishimoto, Y., Kernbauer-Hölzl, E., Schuster, S.L., Sota, S., Venzon, M., 985 Dallari, S., Galvao Neto, A., Hine, A., Hudesman, D., et al. (2019). IFN-I and IL-22 mediate 986 protective effects of intestinal viral infection. Nature Microbiology 4, 1737-1749.

987 Norman, J.M., Handley, S.A., Baldridge, M.T., Droit, L., Liu, C.Y., Keller, B.C., Kambal, A., 988 Monaco, C.L., Zhao, G., Fleshner, P., et al. (2015). Disease-specific alterations in the enteric 989 virome in inflammatory bowel disease. Cell 160, 447-460.

990 Nyström, N., Berg, T., Lundin, E., Skog, O., Hansson, I., Frisk, G., Juko-Pecirep, I., Nilsson, 991 M., Gyllensten, U., Finkel, Y., et al. (2013). Human enterovirus species B in ileocecal Crohn's 992 disease. Clinical and Translational Gastroenterology 4, e38.

993 Pane, J.A., and Coulson, B.S. (2015). Lessons from the mouse: potential contribution of 994 bystander lymphocyte activation by viruses to human type 1 diabetes. Diabetologia 58, 11499951159.

996 Png, C.W., Lindén, S.K., Gilshenan, K.S., Zoetendal, E.G., McSweeney, C.S., Sly, L.I., 997 McGuckin, M.A., and Florin, T.H.J. (2010). Mucolytic bacteria with increased prevalence in IBD 998 mucosa augment in vitro utilization of mucin by other bacteria. The American Journal of 999 Gastroenterology 105, 2420-2428. 
Ramanan, D., Tang, M.S., Bowcutt, R., Loke, P., and Cadwell, K. (2014). Bacterial sensor Nod2 prevents inflammation of the small intestine by restricting the expansion of the commensal Bacteroides vulgatus. Immunity 41, 311-324.

1003 Ramanan, D., Bowcutt, R., Lee, S.C., Tang, M.S., Kurtz, Z.D., Ding, Y., Honda, K., Gause, 1004 W.C., Blaser, M.J., Bonneau, R.A., et al. (2016). Helminth infection promotes colonization resistance via type 2 immunity. Science 352, 608-612.

1006 Rath, H.C., Wilson, K.H., and Sartor, R.B. (1999). Differential induction of colitis and gastritis 1007 in HLA-B27 transgenic rats selectively colonized with Bacteroides vulgatus or Escherichia coli. 1008 Infection and Immunity 67, 2969-2974.

1009 Round, J.L., and Mazmanian, S.K. (2009). The gut microbiota shapes intestinal immune 1010 responses during health and disease. Nature Reviews Immunology 9, 313-323.

1011 Sefik, E., Geva-Zatorsky, N., Oh, S., Konnikova, L., Zemmour, D., McGuire, A.M., Burzyn, 1012 D., Ortiz-Lopez, A., Lobera, M., Yang, J., et al. (2015a). Individual intestinal symbionts induce a 1013 distinct population of ROR $\gamma+$ regulatory T cells. Science 349, 993-997.

1014 Sefik, E., Geva-Zatorsky, N., Oh, S., Konnikova, L., Zemmour, D., McGuire, A.M., Burzyn, 1015 D., Ortiz-Lopez, A., Lobera, M., Yang, J., et al. (2015b). Individual intestinal symbionts induce a 1016 distinct population of ROR $\gamma+$ regulatory T cells. Science 349, 993-997.

1017 Šestan, M., Marinović, S., Kavazović, I., Cekinović, Đ., Wueest, S., Turk Wensveen, T., Brizić, 1018 I., Jonjić, S., Konrad, D., Wensveen, F., et al. (2018). Virus-Induced Interferon- $\gamma$ Causes Insulin 1019 Resistance in Skeletal Muscle and Derails Glycemic Control in Obesity. Immunity 49.

1020 Shaffer, A.L., Lin, K.I., Kuo, T.C., Yu, X., Hurt, E.M., Rosenwald, A., Giltnane, J.M., Yang, 1021 L., Zhao, H., Calame, K., et al. (2002). Blimp-1 orchestrates plasma cell differentiation by 1022 extinguishing the mature B cell gene expression program. Immunity 17, 51-62.

Shi, Z., Zou, J., Zhang, Z., Zhao, X., Noriega, J., Zhang, B., Zhao, C., Ingle, H., Bittinger, K., 1024 Mattei, L.M., et al. (2019). Segmented Filamentous Bacteria Prevent and Cure Rotavirus Infection. 1025 Cell 179, 644-658.e13.

1026 Sutherland, D.M., Aravamudhan, P., Dietrich, M.H., Stehle, T., and Dermody, T.S. (2018). 1027 Reovirus Neurotropism and Virulence Are Dictated by Sequences in the Head Domain of the Viral 1028 Attachment Protein. Journal of Virology 92.

1029 Szabo, S., Kim, S., Costa, G., Zhang, X., Fathman, C., and Glimcher, L. (2000). A Novel 1030 Transcription Factor, T-bet, Directs Th1 Lineage Commitment. Cell 100, 655-669. 
Takahashi, K., Nakagawasai, O., Nemoto, W., Odaira, T., Sakuma, W., Onogi, H., Nishijima, H., Furihata, R., Nemoto, Y., Iwasa, H., et al. (2019). Effect of Enterococcus faecalis 2001 on colitis and depressive-like behavior in dextran sulfate sodium-treated mice: involvement of the brain-gut axis. Journal of Neuroinflammation 16, 201.

Tan, T.G., Sefik, E., Geva-Zatorsky, N., Kua, L., Naskar, D., Teng, F., Pasman, L., Ortiz-Lopez, A., Jupp, R., Wu, H.J.J., et al. (2016). Identifying species of symbiont bacteria from the human 1037 gut that, alone, can induce intestinal Th17 cells in mice. Proceedings of the National Academy of 1038 Sciences of the United States of America 113, E8141-E8150.

Tomov, V.T., Palko, O., Lau, C.W., Pattekar, A., Sun, Y., Tacheva, R., Bengsch, B., Manne,

1040 S., Cosma, G.L., Eisenlohr, L.C., et al. (2017). Differentiation and Protective Capacity of Virus1041 Specific CD8+ T Cells Suggest Murine Norovirus Persistence in an Immune-Privileged Enteric Niche. Immunity 47, 723-738.e5.

1043 Ungaro, F., Massimino, L., Furfaro, F., Rimoldi, V., Peyrin-Biroulet, L., D’Alessio, S., and 1044 Danese, S. (2019). Metagenomic analysis of intestinal mucosa revealed a specific eukaryotic gut virome signature in early-diagnosed inflammatory bowel disease. Gut Microbes 10, 149-158. Polio Vaccine on Diarrheal Burden and Etiology Among Bangladeshi Infants. Clinical Infectious Diseases 65, 414-419.

1050 Vehik, K., Lynch, K.F., Wong, M.C., Tian, X., Ross, M.C., Gibbs, R.A., Ajami, N.J., Petrosino, J.F., Rewers, M., Toppari, J., et al. (2019). Prospective virome analyses in young children at increased genetic risk for type 1 diabetes. Nature Medicine 25, 1865-1872.

1053 Wang, S., Hibberd, M.L., Pettersson, S., and Lee, Y.K. (2014). Enterococcus faecalis from 1054 Healthy Infants Modulates Inflammation through MAPK Signaling Pathways. PLoS ONE 9, 1055 e97523.

1056 Winkle, J.A. van, Robinson, B.A., Peters, A.M., Li, L., Nouboussi, R. v., Mack, M., and Nice, 1057 T.J. (2018). Persistence of systemic murine norovirus is maintained by inflammatory recruitment 1058 of susceptible myeloid cells. Cell Host \& Microbe 24, 665.

1059 Yang, J.Y., Kim, M.S., Kim, E., Cheon, J.H., Lee, Y.S., Kim, Y., Lee, S.H., Seo, S.U., Shin, 1060 S.H., Choi, S.S., et al. (2016). Enteric Viruses Ameliorate Gut Inflammation via Toll-like Receptor 10613 and Toll-like Receptor 7-Mediated Interferon- $\beta$ Production. Immunity 44, 889-900. 
1062 Yeung, F., Chen, Y.H., Lin, J. da, Leung, J.M., McCauley, C., Devlin, J.C., Hansen, C.,

1063 Cronkite, A., Stephens, Z., Drake-Dunn, C., et al. (2020). Altered Immunity of Laboratory Mice

1064 in the Natural Environment Is Associated with Fungal Colonization. Cell Host and Microbe 27, 1065 809-822.e6.

1066 Yokoyama, C.C., Loh, J., Zhao, G., Stappenbeck, T.S., Wang, D., Huang, H. v., Virgin, H.W., 1067 and Thackray, L.B. (2012). Adaptive Immunity Restricts Replication of Novel Murine 1068 Astroviruses. Journal of Virology 86, 12262-12270.

1069 Yu, S., Balasubramanian, I., Laubitz, D., Tong, K., Bandyopadhyay, S., Lin, X., Flores, J., 1070 Singh, R., Liu, Y., Macazana, C., et al. (2020). Paneth Cell-Derived Lysozyme Defines the 1071 Composition of Mucolytic Microbiota and the Inflammatory Tone of the Intestine. Immunity 53, 1072 398-416.e8.

1073 Zhao, G., Vatanen, T., Droit, L., Park, A., Kostic, A.D., Poon, T.W., Vlamakis, H., Siljander, 1074 H., Härkönen, T., Hämäläinen, A.-M., et al. (2017). Intestinal virome changes precede 1075 autoimmunity in type I diabetes-susceptible children. Proceedings of the National Academy of 1076 Sciences of the United States of America 114, E6166-E6175. 